\title{
Unspoken Criticism: Audiovisual Forms of Critique as Fair Use
}

\author{
Alec Fisher
}

\section{INTRODUCTION}

Imagine a short video from a film critic highlighting the latest superhero summer blockbuster. First, we see a few seconds of the big action finale from the copyrighted film. The superhero flies through the air, zipping between skyscrapers at breakneck speed. The video cuts to a clip of the critic, in closeup, yawning for several seconds. Then, it cuts back to the film, and we see the superhero engaged in the film's climactic battle, pummeling the villain with superhuman strength. Next, it cuts back to the critic, who is now asleep and snoring loudly. The video ends. Is the resulting video a work of criticism? It may depend on whom you ask. For a court assessing criticism for fair use purposes, the answer is currently unclear.

In recent years, the rise of online social media platforms and increased access to the tools of creative expression - smartphone cameras, and photo and video editing software, to name a few-have led to the proliferation of audiovisual criticism on the internet. ${ }^{1}$ Online audiovisual criticism is now so ubiquitous that numerous YouTube channels dedicated to film and television criticism boast viewership in the hundreds of millions. ${ }^{2}$ Yet, as new technologies have lowered the barriers to entry for creators of works of criticism, these technologies have also fostered a creative evolution of criticism in ways that present novel questions for copyright law.

* J.D. Candidate, Columbia Law School, Class of 2021; B.A., Florida State University; Editorin-Chief, Columbia Journal of Law \& the Arts, 2020-21. Many thanks to Professor Tim Wu for his guidance, wisdom, and candor throughout the writing process. Thanks also to David A. Fischer for his many helpful edits, and to the hard work of the staff of the Columbia Journal of Law \& the Arts.

1. In this Note, I use the term "audiovisual criticism" to refer to a work of criticism in a watchable video format that utilizes video clips, spoken commentary, sound effects, visual effects, and/or other film editing techniques to further the intended criticism. Works of audiovisual criticism can have any creative work as their object, including books, music, live theater, television shows, films, original online video content, or other works of audiovisual criticism.

2. See, e.g., RedLetterMedia, YouTUBE, https://perma.cc/M7EU-VEET (last visited Dec. 26, 2020) (over 663 million channel views as of this writing); Lindsay Ellis, YOUTUBE, https://perma.cc/DD82-8XF7 (last visited Dec. 26, 2020) (over 105 million channel views as of this writing); Nerdwriter1, YouTUBE, https://perma.cc/62H4-A2NQ (last visited Dec. 26, 2020) (over 215 million channel views as of this writing).

(C) 2021 Fisher. This is an open access article distributed under the terms of the Creative Commons Attribution License, which permits unrestricted use, distribution, and reproduction, provided the original author and source are credited. 
On YouTube and other video sharing sites, reaction videos have become a popular form of audiovisual criticism. Reaction videos are online videos that contain, quite simply, "footage of people reacting to things." 3 Reaction videos traditionally include footage of the video participant intercut with or superimposed over the pre-existing, and often copyrighted, video footage to which they are reacting. This reaction is frequently extemporaneous, though it need not be, and it may or may not include other graphical, visual, or audio elements that lend emphasis and context to the participant's commentary. Because reaction videos utilize film-specific conventions and techniques to enhance their commentary, reaction videos sometimes criticize the underlying copyrighted work in a non-spoken, visual manner. Criticism is a classic form of fair use - an affirmative defense to copyright infringement. However, the traditional analysis for fair use criticism has focused heavily on a work's text or dialogue, with less emphasis placed on a work's non-textual or non-spoken elements. As reaction videos and other forms of online audiovisual criticism rise in popularity, courts assessing these videos as works of criticism for fair use purposes have struggled to apply the traditional fair use framework to these types of online criticism.

This Note argues that the traditional legal framework for analyzing a work of alleged criticism as fair use is particularly constraining for YouTube reaction videos and other audiovisual forms of criticism that largely critique or comment on an original work in a non-spoken, visual manner. It discusses the emphasis that the current fair use jurisprudence places on spoken and written critical elements when undertaking a fair use analysis of a work of criticism, then advocates for a new conception of fair use criticism that incorporates film-specific analytical techniques and concepts when analyzing the critical elements of online audiovisual works. Part I discusses the statutory codification of the fair use doctrine in copyright law and how the doctrine has been shaped through the years by subsequent judicial interpretation. Part I also discusses the history of YouTube reaction videos as a unique audiovisual format. Part II explores the ways in which courts have recently applied the fair use doctrine to alleged works of audiovisual criticism and the emphasis courts place on spoken and written critical elements. Part III argues that courts assessing online audiovisual works as alleged works of criticism should incorporate analytical tools and interpretive theories commonly utilized in film studies contexts - including an analysis of editing, shot composition, and camera movement-when parsing alleged works of audiovisual criticism for transformativeness under factor one of the fair use test. Finally, Part IV uses a recently decided fair use case out of the Southern District of New York as a real-life example to explore how a court could apply film-specific analytical tools to more accurately identify and assess the critical elements of a work of audiovisual criticism for fair use purposes.

3. Sam Anderson, Watching People Watching People Watching, N.Y. TimES MAG. (Nov. 25, 2011), https://perma.cc/VKF2-WSVX. 


\section{THE FAIR USE DOCTRINE, REACTION VIDEOS, AND ONLINE VIDEO CRITICISM}

\section{A. Copyright LAW And the FAIR USe Doctrine}

To understand the issues surrounding audiovisual criticism and fair use, it is helpful to trace the history and evolution of the fair use doctrine. Fair use is an affirmative defense to copyright infringement. As such, if a defendant can successfully show that her use of a copyrighted work is fair use, she will not be found liable for copyright infringement. Thus, the rights afforded to authors under copyright law are necessarily limited by the defense of fair use.

The legal framework for copyright protection stretches back to the founding of the United States. The Constitution gives Congress the power to "secur[e] for limited Times to Authors and Inventors the exclusive Right to their respective Writings and Discoveries."4 Today, federal copyright law affords copyright owners a series of exclusive rights over their original work. Per 17 U.S.C. $\S 106$, copyright owners have the exclusive right to reproduce their copyrighted work, to prepare derivative works, to distribute copies of the copyrighted work, to perform the work publicly, to display the work publicly, and, for sound recordings, to perform the work publicly by means of a digital audio transmission. ${ }^{5}$ When an individual violates any of a copyright holder's exclusive rights under $\S 106$ without authorization or permission to do so, that individual is guilty of copyright infringement. ${ }^{6}$ However, the statutory text makes clear that the exclusive rights enumerated in $\S 106$ are subject to the defenses listed in $\S \S 107$ through $122 .^{7}$ Among these defenses is the affirmative defense of fair use, outlined in $\S 107 .{ }^{8}$ If an individual's alleged use of a copyrighted work is found to be fair use under $\S 107$, that individual is not liable for copyright infringement.

Although the doctrine of fair use has existed in the law in some form since the earliest days of the United States, ${ }^{9}$ the equitable doctrine of fair use was codified into

\footnotetext{
4. U.S. CONST. art I, § 8, cl. 8 .

5. 17 U.S.C. $\S 106$.

6. See 4 Melville B. Nimmer \& DAVid Nimmer, Nimmer on Copyright $§ 13.04$ (2019) [hereinafter NIMMER ON COPYRIGHT] ("A defendant will prevail in an infringement action either because the plaintiff has failed to establish by a preponderance of the evidence the required elements of ownership and copying, or by reason of the availability of a defense, such as a license or assignment from the copyright owner, joint ownership of the work, jurisdictional defects, limitations notice defects or res judicata.").

7. 17 U.S.C. $\$ 106$

8. Id. $\S 107$.

9. See Campbell v. Acuff-Rose Music, Inc., 510 U.S. 569, 575-76 (1994) ("From the infancy of copyright protection, some opportunity for fair use of copyrighted materials has been thought necessary to fulfill copyright's very purpose, '[t]o promote the Progress of Science and useful Arts' ... . In copyright cases brought under the Statute of Anne of 1710, English courts held that in some instances 'fair abridgements' would not infringe an author's rights ... and although the First Congress enacted our initial copyright statute, Act of May 31, 1790, 1 Stat. 124, without any explicit reference to 'fair use,' as it later came to be known, the doctrine was recognized by the American courts nonetheless.") (citations and footnotes omitted).
} 
the statutory scheme for the first time in the Copyright Act of $1976 .{ }^{10}$ Per the statutory text of the Act:

In determining whether the use made of a work in any particular case is a fair use the factors to be considered shall include-

(1) the purpose and character of the use, including whether such use is of a commercial nature or is for nonprofit educational purposes;

(2) the nature of the copyrighted work;

(3) the amount and substantiality of the portion used in relation to the copyrighted work as a whole; and

(4) the effect of the use upon the potential market for or value of the copyrighted work. ${ }^{11}$

The Supreme Court has held that fair use analysis cannot be "simplified with bright-line rules," but rather "calls for a case-by-case analysis." 12 Therefore, courts must assess and weigh each factor of the fair use statute in order to determine whether or not an alleged infringement constitutes fair use. No single factor is dispositive; instead, all factors "are to be explored, and the results weighed together, in light of the purposes of copyright." 13

The first factor of the fair use statute requires an assessment of the purpose and character of the work containing the alleged infringement. In Campbell v. AcuffRose Music, Inc., the Supreme Court explained that this factor asks a court to assess "whether and to what extent the new work is "transformative." 14 The transformative nature of a work is determined by examining whether the new work "merely supersedes the objects" of the original work "or instead adds something new, with a further purpose or different character, altering the first with new expression, meaning, or message." 15 For example, one court found that a parodic reimagining of the novel Gone With the Wind was transformative under factor one because the new book subverted the original novel's "traditional race roles" and "generally set[] out to demystify [Gone With the Wind] and strip the romanticism from Mitchell's specific account of this period of our history." 16 The Second Circuit has cautioned that "[t]he word 'transformative' cannot be taken too literally .... It is rather a suggestive symbol for a complex thought," suggesting further that the kinds of uses likely to be transformative involve a "transformative purpose" as opposed to mere "changes in form." ${ }^{17}$ In recent years, factor one's transformative use test has begun to approach "total dominance in the fair use jurisprudence," with a finding of

10. 4 NIMMER ON COPYRIGHT, supra note $6, \S 13.05$.

11. 17 U.S.C. $\$ 107$.

12. Campbell, 510 U.S. at 577.

13. Id. at 578 .

14. Id. at 579 (quoting Pierre Leval, Toward a Fair Use Standard, 103 HARV. L. REV. 1105, 1111 (1990)).

15. Id.

16. Suntrust Bank v. Houghton Mifflin Co., 268 F.3d 1257, 1270 (11th Cir. 2001) (ultimately finding that the work in question was fair use).

17. Authors Guild v. Google, Inc., 804 F.3d 202, 214-15 (2d Cir. 2015). 
transformative use frequently overshadowing every other factor of the fair use test. ${ }^{18}$ The first factor also considers whether the work was taken for a commercial or noncommercial purpose, with the commerciality of a work tending "to weigh against a finding of fair use." 19

The second factor of the fair use test looks to the nature of the copyrighted work. This factor often assesses "whether the original work is "creative' as opposed to "factual."" 20 Works that are creative "will generally receive greater copyright protection." ${ }^{21}$ However, at least one court has noted that "[t]he second factor has rarely played a significant role in the determination of a fair use dispute." ${ }^{22}$ Although courts assessing fair use will include an analysis of factor two, this "factor more typically recedes into insignificance in the greater fair use calculus." 23

The third factor of the fair use test assesses the amount and substantiality of the copyrighted work used in the allegedly infringing work, in relation to the copyrighted work as a whole. When assessing this factor, a court asks whether "'the quantity and value of the materials used . ... are reasonable in relation to the purpose of the copying." ${ }^{24}$ To this end, a factor three analysis looks not only at the sheer amount of the original work copied within the allegedly infringing work, but also "the qualitative nature of the taking." 25 This requires a court to make an assessment of the importance of the portion of the original work taken, bearing in mind that a quantitatively small portion may nonetheless constitute "the heart" of the original work - the "qualitative[] embodi[ment]" of the original work's "distinctive expression." "26 In Harper \& Row Publishers, Inc. v. Nation Enterprises, the Supreme Court found that although a magazine's copying of 300 words from President Ford's memoirs constituted a small portion of the entire manuscript, the magazine had taken "the most interesting and moving parts of the entire manuscript," and thus the portions taken were qualitatively significant. ${ }^{27}$ In short, a court's factor three analysis looks at both the quantity of material taken from a copyrighted work in

18. Jiarui Liu, An Empirical Study of Transformative Use in Copyright Law, 22 STAN. TECH. L. REV. 163, 240 (2019). See also id. ("Of all the dispositive decisions that upheld transformative use, 94\% eventually led to a finding of fair use.... [A] finding of transformative use overrides findings of commercial purpose and bad faith under factor one, makes irrelevant the issue of whether the original work is creative or unpublished under factor two, stretches the extent of copying permitted under factor three towards $100 \%$ verbatim reproduction, and precludes the evidence on damage to the primary or derivative market under factor four even though there exists a well-functioning market for the use.").

19. Campbell, 510 U.S. at 585 (quoting Harper \& Row Publishers, Inc. v. Nation Enters., 471 U.S. $539,562(1985))$.

20. Bill Graham Archives, LLC v. Dorling Kindersley Ltd., 386 F. Supp. 2d 324, 330 (S.D.N.Y. 2005) (quoting Richard Feiner \& Co. v. H.R. Indus., Inc., 10 F. Supp. 2d 310, 314 (S.D.N.Y. 1998)).

21. Id.

22. Authors Guild, 804 F.3d at 220. See also Suntrust Bank v. Houghton Mifflin Co., 268 F.3d 1257, 1271 (11th Cir. 2001) ("[The second] factor is given little weight in parody cases, however, "since parodies almost invariably copy publicly known, expressive works."') (quoting Campbell, 510 U.S. at 586).

23. 4 NIMMER ON COPYRIGHT, supra note $6, \S 13.05[\mathrm{~A}][2][\mathrm{a}]$.

24. Campbell, 510 U.S. at 586 (quoting Folsom v. Marsh, 9 F. Cas. 342, 348 (C.C.D. Mass. 1841)).

25. Harper \& Row Publishers, Inc. v. Nation Enters., 471 U.S. 539, 565 (1985).

26. Id.

27. Id. (ultimately holding that the defendant's copying was not fair use). 
relation to its whole, as well as the qualitative value of the material taken in relation to the entire copyrighted work.

The fourth factor of the fair use test directs courts "to consider the extent of the market harm caused by the particular actions of the alleged infringer, as well as 'whether unrestricted and widespread conduct of the sort engaged in by the defendant ... would result in a substantially adverse impact on the potential market' for the original." 28 This assessment must account for the harm done to the markets for both the original work and derivative works. ${ }^{29}$ Not every potential licensing market is considered a relevant market for the purpose of the fourth factor's market harm inquiry; a court "considers the challenged use's 'impact on potential licensing revenues for traditional, reasonable, or likely to be developed markets." ${ }^{30}$ The fourth factor was once considered "the single most important element of fair use," 31 but its dominance has waned in recent years as courts have placed more weight on factor one's transformative use test. ${ }^{32}$ However, a recent empirical analysis of fair use cases found that factor four continues to be "strongly correlated with fair use outcome[s]."33

While the fair use framework described above has been applied to numerous types of works in the years since the Supreme Court's Campbell decision, not every type of work lends itself to clean, simple, and consistent analysis under this framework. To see how the current fair use framework creates difficult questions of applicability for certain types of creative work, one needn't look any further than the emerging case law surrounding YouTube reaction videos.

\section{B. The Rise of YouTube Reaction Videos}

Reaction videos are a user-created online video format popular on YouTube and other video sharing sites wherein the video's participant films herself reacting to or commenting on third-party video footage. ${ }^{34}$ A popular type of reaction video features the video participant prominently in the frame, slightly off-center, with the footage to which they are reacting "displayed in the corner of the video" frame. ${ }^{35}$

28. Campbell, 510 U.S. at 590 (quoting 3 Melville B. NiMMER \& DAVID NiMMER, NiMMER ON COPYRIGHT $\S 13.05[\mathrm{~A}][2]$ (1993)) (alteration in original).

29. See Harper \& Row, 471 U.S. at 568.

30. TCA Television Corp. v. McCollum, 839 F.3d 168, 186 (2d Cir. 2016) (quoting Am. Geophysical Union v. Texaco Inc., 60 F.3d 913, 930 (2d Cir. 1994)).

31. Harper \& Row, 471 U.S. at 566.

32. "[T] $]$ he transformative use doctrine gradually became central to fair use determinations in many lower courts. As an empirical study by Professor Neil Weinstock Netanel of fair-use cases from 2006 to 2010 concluded, "fair use doctrine today is overwhelmingly dominated by the Leval-Campbell transformative use doctrine." Matthew D. Bunker \& Clay Calvert, The Jurisprudence of Transformation: Intellectual Incoherence and Doctrinal Murkiness Twenty Years After Campbell v. Acuff-Rose Music, 12 DukE L. \& TECH. ReV. 92, 101 (2014) (quoting Neil Weinstock Netanel, Making Sense of Fair Use, 15 LEWIS \& CLARK L. REV. 715, 736 (2011)).

33. Liu, supra note 18, at 198 ("Of the 238 dispositive decisions sampled, 121 found factor four favored fair use, of which $112(92.6 \%)$ found fair use ....").

34. Anderson, supra note 3.

35. Kritika Bansal, Reaction Channels on YouTube-Like Them or Hate Them but You Can't Ignore Them, VIDOOLY.COM, https://perma.cc/AYY9-V79M (last visited Oct. 26, 2020). 
The earliest forms of the reaction video largely focused on "captur[ing] moments of surprise" spurred by the contents of frightening or startling video clips, while more recent reaction videos "tend to focus on reactions to pieces of popular culture such as movie trailers, music videos, television shows, or other YouTube videos." ${ }^{\prime 36}$ Traditionally, reaction videos feature a participant reacting extemporaneously to video footage, capturing the participant's reaction in real time, ${ }^{37}$ but reaction videos can also include pre-scripted material and other planned dialogue and visual elements. $^{38}$

Although reaction videos were present on the Internet in some form prior to YouTube, ${ }^{39}$ several commentators trace the rise of online reaction videos to the YouTube website in $2007 .{ }^{40}$ Specifically, commentators generally trace the rise in reaction videos as a distinct video format to the YouTube video, "2 Girls 1 Cup," a "gross-out fetish porn clip" that "bubbled up into the popular consciousness" in 2007. ${ }^{41}$ According to one commentator, "[t]he video was so foul ... that it forced a kind of psychological schism. It was unwatchable, and yet it had to be watched. People solved this paradox by 'watching' it: performing their spectation, via Web cam, as a public service." ${ }^{42}$ By aiming a webcam at the participant's face, filming the participant's reaction to the video, and uploading the reaction to the YouTube website, these original reaction videos allowed others "to watch this taboo thing by proxy, to experience its dangerous thrill without having to encounter it directly." 43

Other early YouTube reaction videos mirrored this format, framing the video to capture a participant's real time reaction as she watched a video containing shocking, fear-inducing, or humorous content. ${ }^{44}$ Over time, the subject matter of reaction

36. Joseph Daniel Barden, Where's the Fair Use? Participatory Culture, Creativity, and Copyright on YouTube 78 (May 2018) (M.A. thesis, University of Wisconsin-Milwaukee), https://perma.cc/ZZ2EEBQG.

37. See, e.g., Linor Oren - voice teacher, Opera singer's reaction: how good was Freddie Mercury in 1981?, YOUTUBE (Nov. 27, 2018), https://perma.cc/EBT2-P73F.

38. See, e.g., Corridor Crew, VFX Artists React to Bad \& Great CGi 18, YouTuBE (Jan. 11, 2020), https://perma.cc/DE7M-44MS.

39. For example, the technology magazine Wired credits the video clip "badday.mpg" as being one of the "Internet's first viral videos." Joe Viex, The Strange History of One of the Internet's First Viral Videos, WIRED (Jan. 12, 2018), https://perma.cc/7JCG-VBNP. Released in 1997, the short video clip features a "man sit[ting] in a cubicle . . . pound[ing] his keyboard in frustration . . . and swing[ing] it like a baseball bat at his screen." Id. "The clip began to circulate online, mostly via email," and garnered enough of a fanbase that someone "made a fan site" for the video where viewers could download and share the clip. Id. In response to the video, many viewers "filmed their own versions" of the "badday.mpg" clip. Id. These filmed re-creations and reactions to the "badday.mpg" video share many elements in common with the modern YouTube reaction video genre.

40. See Anderson, supra note 3; Eric Skelton, The Fascinating Rise of YouTube Music Reaction Videos, COMPLEX (Jan. 29, 2018), https://perma.cc/6HLK-3VRL.

41. See Anderson, supra note 3 .

42. Id.

43. Id.

44. According to the website Know Your Meme, other early YouTube reaction videos include "a video of a child reacting to the Scary Maze Game" - a prank video game wherein a picture of Linda Blair from the movie The Exorcist, appears suddenly in the middle of a video game level to induce a jump scare from the viewer-and "footage of a family reacting to a FAIL video" in which a teenage girl falls off a 
videos began to skew away from shocking and salacious videos and towards clips from television, movies, and pop culture. ${ }^{45}$ In 2013, for example, a popular type of YouTube reaction video featured the reactions of unsuspecting viewers of the television show Game of Thrones who had never read the original source material "gasping, weeping, and shouting" as they watched "The Rains of Castamere," an episode notorious for its "shocking plot twists." 46

The reaction video genre has exploded in popularity on YouTube since 2007, with the top reaction videos on YouTube attracting tens of millions of views and top reaction video channels garnering tens of millions of subscribers. ${ }^{47}$ In response to this popularity, some academics have theorized that the cultural fascination with reaction videos may be linked to the biology of the human brain. ${ }^{48}$ Today, reaction videos are commonly created to respond to the release of movie trailers for anticipated blockbusters, ${ }^{49}$ album releases, ${ }^{50}$ and pop culture moments. ${ }^{51}$

coffee table. Reaction Videos, KNOw YouR MEME, https://knowyourmeme.com/memes/reaction-videos (last visited Oct. 31, 2020).

45. Popular subcategories of reaction videos include "crowds in sports bars flipping out over touchdowns" and "teenage superfans crying at long-awaited movie trailers." Anderson, supra note 3.

46. Laura Hudson, What's Behind Our Obsession with Game of Thrones Reaction Videos, WIRED (June 5, 2014), https://perma.cc/3YNC-667L.

47. See e.g., REACT, Kids React to Gay Marriage, YouTUBE (Nov. 3, 2013), https://perma.cc/DR3J-36TQ (over 44 million views of this video and over 20 million channel subscribers as of this writing); Reaction Time, Kids Who Beat The System (Hilarious), YouTuBE (Oct. 26, 2017), https://perma.cc/TDM9-SZ8K (over 37 million views of this video and over 15 million channel subscribers as of this writing); REPLAY, Elders Play Grand Theft Auto V (Elders React: Gaming), YouTUBE (Jan. 21, 2015), https://perma.cc/L3WU-AAZM (over 30 million views of this video and over 12 million channel subscribers as of this writing). YouTube's subscribe function allows users to follow the channels most relevant to their interests and receive notifications when those channels post new videos. As such, the number of subscribers a YouTube channel has often corresponds with that channel's overall popularity on the site.

48. Lisa Aziz-Zadeh, an associate professor at the Brain and Creativity Institute at the University of Southern California, theorized that there is "something in our brains called mirror neurons that might explain why people get joy out of watching strangers react ... on the internet." Skelton, supra note 40. Aziz-Zadeh explains that "[m]irror neurons may enable us to automatically simulate other people's experiences. Thus when we see someone doing an action that is joyful (like rocking out to music), we might share the joy they experience because we know what it feels like to rock out to music ourselves." $I d$. Other researchers have posited that "[e]mpathy may be another reason why react videos are so easy to watch." Valentina Palladino, The Science Behind the Insane Popularity of "React" Videos on YouTube, ARsTECHNICA (Apr. 3, 2016), https://perma.cc/ZBC5-KPBQ. According to Andrea Weinstein, a clinical psychologist and psychology doctoral intern, "[w]hen you watch someone react to something with a big response, it's much easier to empathize with them because you know exactly what they're feeling. ... We feel immediately bonded to them because we say, 'Yep, I would have that reaction, too." II. Summarizing Weinstein's argument, one commentator explained that watching reaction videos "provide[s] a two-fold experience: we feel satisfied because we know the emotions being conveyed in the video, and we bond with the reactor because we can share their emotions." Id.

49. See e.g., Apocaflix! Movies, STAR WARS: THE RISE OF SKYWALKER Final Trailer Reaction!, YouTuBE (Oct. 21, 2019), https://perma.cc/HWG6-2JL9.

50. See e.g., Nina Schofield, CARLY RAE JEPSEN - Dedicated [Musician's] Reaction \& Review!, YouTUBE (May 17, 2019), https://perma.cc/LU3Y-XL5R.

51. See e.g., Finely Taylored, Oscars 2020 | Best Director REACTION!, YouTuBE (Feb. 9, 2020), https://perma.cc/2YLN-TRX5. 
As reaction videos grow in popularity, various copyright and other legal issues have begun to surface.52 Because reaction videos typically use a copyrighted work as the source material to which a participant reacts, several YouTube reaction video creators have expressed concern over the fear of being sued for copyright infringement. Since the fair use of a reaction video depends in large part on the use to which the clip is put and the commentary given by the participant watching the copyrighted clip - in sum, the reaction-YouTube creators who make reaction videos often operate under a veil of legal uncertainty. While a reaction video that clearly criticizes, parodies, or provides commentary on its object is more likely to be an instance of fair use, many popular reaction videos simply portray the participant making "facial expressions, guttural noises, and interspersed comments about their feelings" on the object video. ${ }^{53}$ Under the current legal framework for analyzing fair use, these extemporaneous exhortations and exclamatory remarks may or may not be sufficiently transformative to constitute fair use.

Recently, the creators of the YouTube reaction video channel MxR Plays made headlines when they revealed they had been sent a $\$ 6,000$ bill from viral video licensor Jukin Media for using four Jukin video clips in various reaction videos. ${ }^{54}$ The MxR Plays creators claimed they were being extorted by Jukin and worried that failure to pay the sum demanded would result in the invocation of YouTube's "three strikes" rule for alleged copyright offenses, under which their YouTube channel could be subject to termination. ${ }^{55}$ At the time, several commentators questioned whether or not MxR Plays could successfully invoke the fair use defense, with one YouTube creator and copyright lawyer indicating he thought their ability to

52. In one prominent example, Fine Brothers Entertainment, a media company that oversees several popular reaction video YouTube channels, faced intense backlash in 2016 after attempting to trademark the term "React" as part of a proposed licensing scheme, which "would let other video-makers use the 'react' title and assets such as their graphics and music." Chris Foxx, Fine Brothers Spark Fury with YouTube Trademark Attempt, BBC News (Feb. 1, 2016), https://perma.cc/EU2U-SFVE. Though the trademark would not have stopped other creators from filming videos in the reaction video format, several YouTube creators feared that the creators behind Fine Brothers Entertainment would somehow use the trademark "to stifle competition" in the reaction video space Id. After more than 400,000 users unsubscribed from their channel in protest, the company rescinded its trademark application. Alex AbadSantos, The Fine Brothers' Reaction Video Controversy, Explained, Vox (Feb. 3, 2016), https://www.vox.com/2016/2/3/10906032/fine-brothers-youtube-trademark.

53. Jessica Vogele, Note, Where's the Fair Use? The Takedown of Let's Play and Reaction Videos on YouTube and the Need for Comprehensive DMCA Reform, 33 TOURO L. REV. 589, 599 (2017).

54. See Tom Gerken, YouTubers Face £4,600 Bill over Copyright Claims, BBC News (Jan. 13, 2020), https://perma.cc/2VWJ-S27L.

55. See Charlie Wood, Two YouTubers with 2 Million Subscribers Face a $\$ 6,000$ Bill over a Copyright Complaint and Risk Losing Their Channel if They Don't Pay Up, BUS. INSIDER (Jan. 14, 2020), https://perma.cc/E2N3-R3LB. A copyright strike is an internal YouTube action whereby YouTube issues a warning - a strike - to a YouTube channel in response to a takedown notice from a copyright owner alleging that one of the channel's videos contains her copyrighted work. When a YouTube channel receives three copyright strikes in a ninety-day period, the YouTube user's "account, along with any associated channels, is subject to termination." Copyright Strike Basics, YouTuBE HelP, https://perma.cc/LH7K-A3F5 (last visited Oct. 26, 2020). 
successfully argue fair use was "right on the line." ${ }^{.56}$ MxR Plays settled the matter privately with Jukin Media in January 2020. ${ }^{57}$

As fears over the threat of copyright strikes and suits for copyright infringement have grown, creators of YouTube reaction videos have attempted to help their community by uploading YouTube videos that seek to explain how to avoid copyright infringement when making a reaction video. ${ }^{58}$ However, these explanation videos may inadvertently mischaracterize or misapply copyright law, leading to further confusion. ${ }^{59}$ Ultimately, as reaction videos continue to grow in popularity, uncertainty over the boundaries of fair use protection for reaction videos will become a more frequently litigated issue, forcing courts to consider the extent to which YouTube reaction videos are protected by fair use.

\section{COURTS STRUGGLE WITH NON-SPOKEN CRITICAL ELEMENTS WHEN ASSESSING AUDIOVISUAL WORKS AS FAIR USE CRITICISM}

One potentially winning argument that the makers of reaction videos could advance is that their videos are a type of audiovisual criticism. Criticism is, after all, a well-recognized candidate for fair use protection. ${ }^{60}$ Although no type of work is entitled to automatic fair use protection - fair use adjudication requires a "case-bycase analysis" rather than substitutes for the copyrighted original," in line with the goals of the fair use statute. Yet, because reaction videos are an audiovisual format, most - if not all — of the work's critical elements may be nonspoken visual elements that are, at first glance, less clearly critical than the biting prose of a book reviewer or the nuanced critique of a music critic. Courts thus far

56. Gerken, supra note 54.

57. See MxR Plays, update on the Jukin Media situation, YouTUBE (Jan. 15, 2020), https://perma.cc/N2N7-J6PJ.

58. See, e.g., KDUB SOSOLID, How to Avoid Copyright Claims on Reaction Videos!!!, YOUTUBE (Feb. 10, 2019), https://perma.cc/4F42-5ZSY; Messy Nessie, HOW TO MAKE REACTION VIDEOS WITHOUT GETTING COPYRIGHTED 2018, YOUTUBE (Dec. 10, 2018), https://perma.cc/36ZF-6E2J.

59. One of the most common reasons for this confusion is that many YouTube creators conflate U.S. copyright law with YouTube's Content ID system - the internal content-matching software YouTube uses to search for copyrighted works on its site. Some videos explaining how to avoid copyright infringement on YouTube give the advice that a creator will avoid copyright infringement if they use no more than thirty seconds of a copyrighted song, or if they increase the playback speed of the copyrighted video they are using. See, e.g., DJ Kiz Walsh, How to avoid copyright on your live DJ streams, YOUTUBE (Apr. 22, 2020), https://perma.cc/Y8NZ-CSCE. While these tips may help a YouTube creator avoid being flagged by YouTube's Content ID system, these tips have no legal effect.

60. "The defense of fair use ... plays an essential role in copyright law. Without it, any copying of copyrighted material would be a copyright infringement. A book reviewer could not quote from the book he was reviewing without a license from the publisher. Quite apart from the impairment of freedom of expression that would result from giving a copyright holder control over public criticism of his work, to deem such quotation an infringement would greatly reduce the credibility of book reviews, to the detriment of copyright owners as a group . . ..” Ty, Inc. v. Publ'ns Int'l Ltd., 292 F.3d 512, 517 (7th Cir. 2002).

61. Campbell v. Acuff-Rose Music, Inc., 510 U.S. 569, 577 (1994).

62. Ty, Inc., 292 F.3d at 518. 
have shown difficulty recognizing the criticism embodied in an audiovisual work's visual elements, making it more likely that these types of works will not be found to be criticism in the first place. ${ }^{63}$

Part II.A explores the manner in which courts have traditionally analyzed works of criticism as fair use. Then, Part II.B examines recent cases in which courts have been asked to assess YouTube reaction videos as fair use, highlighting the largely text- and dialogue-focused nature of their analyses and the impact this narrow analytical focus has on the overall fair use determination. Next, Part II.C looks at the principle of aesthetic nondiscrimination found in Bleistein $v$. Donaldson Lithographing $C o$. and explains why this principle is compatible with a judicial analysis of the visual and non-spoken elements of a work of audiovisual criticism. Lastly, Part II.D looks at how courts have approached the fair use analysis in the appropriation art context, particularly how courts have shown that they are able to analyze and assess the non-spoken, visual elements of a work in that line of cases.

\section{A. The Origin and Evolution OF Criticism in Fair USE Jurisprudence}

Criticism and review are among the most "universally recognized" types of works that qualify for fair use protection. ${ }^{64}$ Indeed, fair use protection for criticism and commentary are explicitly listed in the fair use statute's preamble as types of works that the fair use law intends to protect. ${ }^{65}$ In the Congressional report preceding the Copyright Act of 1976, Congress listed the "quotation of excerpts in a review or criticism" as an example of an activity "the courts might regard as fair use under the circumstances." ${ }^{966}$ Although quotations for review purposes constitute some of the earliest recognized forms of fair use criticism, ${ }^{67}$ subsequent court decisions have expanded the definition of criticism, finding, for example, that parody is an "ostensibly humorous form[] of criticism." 68

Courts searching for critical content frequently focus on a work's textual or spoken elements. In Campbell v. Acuff-Rose Music, Inc., the Supreme Court assessed a song by the rap group 2 Live Crew that was alleged to be a parody of Roy Orbison's song, "Pretty Woman." In assessing the song's parodic content, the court focused exclusively on the words of the song: "[T] he words of 2 Live Crew's song copy the original's first line, but then quickly degenerate into a play on words, substituting predictable lyrics with shocking ones that derisively demonstrate how bland and banal the Orbison song seems to them." ${ }^{69}$ In a more recent district court case involving an alleged parody of Don Henley's song "The Boys of Summer," the court spent several paragraphs comparing the lyrics of the alleged parody with the

63. See infra Part II.B.

64. 4 NIMMER ON COPYRIGHT, supra note $6, \S 13.05[\mathrm{~B}][5]$.

65. 17 U.S.C. $\S 107$.

66. H.R. REP. NO. 94-1476, at 65 (1976).

67. See Folsom v. Marsh, 9 F. Cas. 342, 344 (C.C.D. Mass. 1841) ("[A] reviewer may fairly cite largely from the original work, if his design be really and truly to use the passages for the purposes of fair and reasonable criticism.").

68. Campbell v. Acuff-Rose Music, Inc., 510 U.S. 569, 579 (1994).

69. Id. at 582 (quotations and alterations omitted). 
original song and relied on this lyrical comparison to conclude that the alleged parody was not fair use because it did not critique or offer commentary on the Henley song. ${ }^{70}$

The focus on text when assessing works for parodic or critical content is not limited to cases of song parody. In Lombardo v. Dr. Seuss Enterprises, the plaintiff sought a declaratory judgement that his comedic one-woman play- "featuring a rather down-and-out 45 year-old version of Cindy-Lou Who" from Dr. Seuss's book How the Grinch Stole Christmas! - was fair use. ${ }^{71}$ The court's fair use analysis focused on the dialogue and plot from the one-woman play. For example, the court found that whereas the Dr. Seuss book uses rhymed couplets to connote a "rhyming innocence," the plaintiff's play critiques this naïve speaking style to show that "rhyming is unsuitable for the real world," as the play "invites the audience to contemplate the juxtaposition of speaking in rhyme and doing prison time."72 Ultimately, the court concluded that the play is a parody that turns "Seussian staples upside down and makes their saccharin qualities objects of ridicule."73 The court relied exclusively on the text of the two works to find that the plaintiff's play was fair use, even though the plaintiff's work was a live stage play that would also incorporate elements like set design, costume design, props, and blocking to fully articulate its parodic commentary on the Dr. Seuss work. ${ }^{74}$

The focus on spoken and verbal elements in fair use criticism analyses presents a problem for YouTube reaction videos and other forms of audiovisual criticism. Because reaction videos are audiovisual works, a critical analysis of a reaction video that focuses exclusively on the spoken commentary in the video omits an assessment of the filmic ${ }^{75}$ and other visual elements inherent to the audiovisual form. When the filmic and visual elements of a reaction video are left unexamined in a fair use analysis, or when these elements are considered in only a fleeting or cursory manner,

70. Henley v. DeVore, 733 F. Supp. 2d 1144, 1157 (C.D. Cal. 2010). For a side-by-side comparison of the lyrics of the two songs, see $i d$. at Appendix A.

71. Lombardo v. Dr. Seuss Enters., 279 F. Supp. 3d 497, 502 (S.D.N.Y. 2017), aff'd, 729 F. App’x 131 (2d Cir. 2018).

72. Id. at 508-09.

73. Id. at 508 .

74. Indeed, the defendant in this case requested that the court not rule on fair use until they received discovery from the plaintiff, including requests for "all set and costume designs" and "deposition testimony from the Play's author, director, set designer and costume designer." Id. at 504. The court rejected the defendant's discovery request because it determined that it could "resolve[] the issue of fair use on a motion for judgment on the pleadings by conducting a side-by-side comparison of the works at issue," making the requested discovery "unnecessary to resolve the fair use issue." Id. 504-05. In rejecting the defendant's discovery request, the court seemingly forgot that the work at issue is a live stage play, not a script for a stage play. Although the script is one element of the play, the totality of the work that constitutes the play includes scenic, costuming, and performative elements. While the court concluded that it could find fair use from the play's script alone, making the discovery process unnecessary, it is also conceivable that the non-textual elements of the play take more from the Dr. Seuss book than is necessary to further the parody, and that this may have affected the court's finding of fair use. Thus, by restricting itself to the text of the play alone, the court offered the parties an incomplete analysis of the parodic content of the plaintiff's work.

75. According to the Merriam-Webster Unabridged Dictionary, filmic is defined as: "of, relating to, resembling, or having the characteristics of motion pictures." Filmic, MERRIAM-WeBSTER UnABR., https://perma.cc/D4ZF-AACY (last visited Mar. 15, 2020). The word filmic is commonly used in the field of film studies, and I will use the term frequently throughout this Note. 
courts run the risk of overlooking or underappreciating the critical content conveyed through these visual elements. This, in turn, can lead to courts undervaluing the extent of the criticism in the audiovisual work at issue or misclassifying the work as an entirely non-critical work.

Although a work need not be a work of criticism in order to qualify for fair use protection, ${ }^{76}$ a 2008 empirical study of fair use cases found that when the defendant's use was deemed by the court to be one of the uses cited in the preamble to the fair use statute, ${ }^{77}$ those "defendants generally enjoyed very high fair use win rates." Specifically, the works of a defendant that contained a critical purpose were held to be fair use in $62.1 \%$ of analyzed district court cases, as opposed to a $38.9 \%$ finding of fair use for the defendant in fair use cases as a whole. ${ }^{79}$ Additionally, in a recent empirical study of transformative use, the study's author determined that, "[o]f the 44 decisions where the defendant's non-parody use nonetheless commented on an element in connection with the original work, $31(70.5 \%)$ found transformative use." ${ }^{\circ 0}$ Per the study, a finding of transformative use "totally dominate[s] the outcome of fair use analysis." 81 Thus, when a court assessing a reaction video as a work of criticism focuses solely on the textual or spoken elements, it is less likely that the reaction video will be found to be a work of criticism, which in turn decreases the likelihood that the reaction video will be found to be fair use.

\section{B. EMPHASIS ON SPOKEN CRITICISM IN REACTION VIDEO CASES}

Courts assessing audiovisual works as fair use criticism frequently prioritize the written and spoken elements of the work, often while deemphasizing or completely excluding any analysis of the work's other elements. ${ }^{82}$ Though case law involving

76. See 4 NimMER ON COPYRIGHT, supra note $6, \S 13.05 \mathrm{n} .38$ ("The purposes listed in the preamble are preceded by 'such as,' which indicates that the listing is "illustrative and not limitative."').

77. Those preambular uses are "criticism, comment, news reporting, teaching (including multiple copies for classroom use), scholarship, or research.” 17 U.S.C. $§ 107$.

78. Barton Beebe, An Empirical Study of U.S. Copyright Fair Use Opinions, 1978-2005, 156 U. PA. L. REV. 549, 609 (2008).

79. Id. at 570,610 . It should be noted that the author of this study ran his data through a regression model and concluded that, "when controlling for the effects of other findings, a finding that the defendant's use fell within one of the preambular categories did not significantly affect the outcome of the fair use test. Instead, as with a finding of bad faith, other considerations appear to have determined the outcome otherwise endorsed by the preambular purposes inquiry." Id. at 609.

80. Liu, supra note 18, at 212 (emphasis added).

81. Id. at 180 . Of the 121 studied cases where the court made a finding of transformative use, $94 \%$ of those cases ultimately held that the defendant's work was fair use. Id.

82. See Caner v. Autry, 16 F. Supp. 3d 689, 710 (W.D. Va. 2014) (emphasizing, inter alia, the critical blog posts accompanying defendant's video as evidence of defendant's criticism of the plaintiff, in a case involving a YouTube video that incorporated footage from plaintiff's copyrighted speeches and presentations); Caner v. Smathers, No. 4:13-CV-494-Y, 2014 WL 12580461, at *3 (N.D. Tex. Apr. 17, 2014) (in a case with the same plaintiff and similar facts, finding without explanation that defendant's posting of video clips of copyrighted presentations on a website was transformative because defendant's purpose was to "criticize a public figure"); Elvis Presley Enters., Inc. v. Passport Video, 349 F.3d 622, 628-29 (9th Cir. 2003) (highlighting an Elvis Presley documentary’s sparse, inconsistently incorporated voice-over narration in finding that the makers of the documentary did not consistently use copyrighted 
YouTube reaction videos continues to emerge as the format grows in popularity, courts who have considered reaction videos as fair use frequently frame the fair use inquiry as an analysis of the video's spoken commentary. ${ }^{83}$ A 2017 district court case, Hosseinzadeh v. Klein, illustrates this phenomenon. ${ }^{84}$

In Hosseinzadeh, filmmaker Matt Hosseinzadeh sued Ethan and Hila Klein, prominent YouTube content creators who run the channel h3h3Productions, for copyright infringement. Hosseinzadeh is a YouTube content creator who uploads original scripted comedy videos to his YouTube channel. One of Hosseinzadeh's original videos, entitled "Bold Guy vs Parkour Girl," is a comedic sketch in which "a fictional character known as 'Bold Guy' . . flirts with a woman and chases her through various sequences." ${ }^{\circ 5}$ The Kleins used several "Bold Guy" video clips in their own YouTube video, "The Big, the BOLD, the Beautiful"- a reaction video in which the Kleins "comment on and criticize the [Bold Guy] video, playing portions of it in the process." ${ }^{\prime 66}$ The Klein video "intersperses relatively short segments of the [Bold Guy] video with long segments of the Kleins' commentary" on the Bold Guy video, including their "mockery of plaintiff's performance and what the defendants consider unrealistic dialog and plotlines. $"{ }^{~} 87$

The Hosseinzadeh court's assessment of the critical content in the Klein reaction video focuses almost exclusively on the spoken commentary that the Kleins provide throughout the video. In finding that the Klein video is "quintessential criticism," the court listed several examples of the criticism the Kleins articulate throughout their video ${ }^{88}$ The court's provided examples of the video's critical content include: when "[d]efendants sarcastically compliment the 'sleeveless hoodie' that Bold Guy wears," when "[d]efendants mock the fact that plaintiff included a line in the script complimenting his own "strong shoulders," and when "Hila Klein expresses irritation with the female character, stating "the female characters [in Bold Guy

Elvis television clips for the purpose of "scholarly critique or historical analysis"); Fuentes v. Mega Media Holdings, Inc., No. 09-22979-CIV, 2011 WL 2601356, at *9 (S.D. Fla. June 9, 2011) (emphasizing the many spoken "comments and criticisms" made by guests on a television program about copyrighted video footage of a Cuban military leader aired by the television program as evidence of the program's transformative use of the copyrighted video footage); Paramount Pictures Corp. v. Axanar Prods., Inc., No. 2:15-CV-09938-RGK-E, 2017 WL 83506, at *8 (C.D. Cal. Jan. 3, 2017) (stating in conclusory terms that, under factor one of the fair use test, the court could not discern any criticism in a fan-made Star Trek short film posted to YouTube); Nat'l Ctr. for Jewish Film v. Riverside Films LLC, No. 5:12-CV-00044ODW, 2012 WL 4052111, at *3 (C.D. Cal. Sept. 14, 2012) (primarily relying on a documentary's use of narration and voiceover to conclude that the documentary filmmakers used copyrighted film clips for the transformative purpose of providing "scholarly commentary").

83. See, e.g., Hosseinzadeh v. Klein, 276 F. Supp. 3d 34 (S.D.N.Y. 2017); Equals Three, LLC v. Jukin Media, Inc., 139 F. Supp. 3d 1094 (C.D. Cal. 2015). For an analysis of a YouTube video that contains no original spoken commentary or verbal elements, see infra Part IV (discussing Hughes v. Benjamin, 437 F. Supp. 3d 382 (S.D.N.Y. 2020)).

84. 276 F. Supp. 3d 34 (S.D.N.Y. 2017).

85. Id. at 40. To view the original Hosseinzadeh video, see Matt Hoss Zone, Bold Guy vs Parkour Girl, YouTuBE (Aug. 11, 2013), https://perma.cc/86KJ-W83D.

86. Hosseinzadeh, 276 F. Supp. 3d at 40. To view the Kleins' reaction video, see h3h3Productions, The Big, the BOLD, the Beautiful (Re-Upload), YouTUBE (Aug. 23, 2017), https://perma.cc/D976-24FE.

87. Hosseinzadeh, 276 F. Supp. 3d at 40.

88. Id. at 45 . 
videos] are always so annoying, and he writes them like that." 89 The court also mentions one example of Ethan Klein's physicality in the video as an example of the video's critical content, stating that "Klein mocks the video's opening title sequence and mimics the movement of the words by performing a dance in his seat." 90 Apart from this one reference to Ethan Klein's physical movement in the video, the court's analysis of the criticism in the Klein reaction video focuses entirely on the video's spoken commentary. The court listed nine examples from the Klein reaction video in bulleted form to illustrate the criticism contained throughout the runtime of the video, and all of the bulleted examples contain quotations or summations of the spoken commentary given by Ethan and Hila Klein in the video.

In addition to the spoken critical commentary cited by the court, there are several visual and filmic elements in the Klein video that enhance the Kleins' criticism that the court either chose not to discuss or did not notice. For example, the Klein video pauses on a screenshot of the YouTube page for the Bold Guy video and dramatically zooms in the image towards the video's view count to express shock and amusement that the video had received over nine million views on YouTube. ${ }^{91}$ Later in the video, the Kleins replay the same footage of Bold Guy jumping over a concrete ledge twice in a row in order to highlight the absurdity of the path Bold Guy takes during the chase sequence. ${ }^{92}$ The Kleins are physically animated throughout much of their reaction video, and their gestures and facial expressions often amplify or underscore the critical commentary they are making. ${ }^{93}$ Although the court found the Klein video to be a work of criticism - and ultimately a work of fair use - the court's analysis of the critical content in the video lacks any discussion of these additional visual critical elements.

In a few cases, courts have mentioned that an audiovisual work's non-spoken, visual elements impacted their fair use analysis. Yet, even when a court assessing an audiovisual work as fair use criticism does articulate a consideration of its visual or filmic elements, the nature of the court's analysis is often not elaborated upon, providing the parties and observers with little understanding of what role the nonspoken elements played in the overall analysis.

In Equals Three, LLC v. Jukin Media, Inc., a 2015 case involving the alleged infringement of copyrighted viral video clips, plaintiff Equals Three sued Jukin Media for a declaratory judgement that the plaintiff's use of certain Jukin viral video clips in its YouTube humor and reaction videos were fair use. ${ }^{94}$ The court grappled with whether or not the plaintiff's videos "comment upon or criticize Jukin's videos" under the first fair use factor, and it undertook a close analysis of several Equals Three videos containing Jukin clips. ${ }^{95}$ The court found that all but one of the Equals

89. Id.

90. Id.

91. h3h3Productions, supra note 86 (at 04:01 of the video).

92. Id. (at 10:12 of the video).

93. In one example, Ethan Klein remarks that the Bold Guy video is "action packed" and has "got it all" while staring directly into the camera, raising his eyebrows in an exaggerated fashion, and rolling his eyes. Id. (at 10:28 of the video).

94. Equals Three, LLC v. Jukin Media, Inc., 139 F. Supp. 3d 1094, 1098 (C.D. Cal. 2015).

95. Id. at 1104 . 
Three videos at issue used the Jukin clips in a transformative way, explaining that the "jokes, narration, graphics, editing, and other elements . . . add something new to Jukin's videos with a different purpose or character." 96

Although the court stated that visual elements like graphics and editing revealed the transformative critical nature of Equals Three's videos, it did not elaborate on how the listed visual and filmic elements support this conclusion. This lack of elaboration is not merely the consequence of a condensed or abbreviated discussion of the fair use inquiry overall. In contrast to the visual elements, the court articulates a nuanced and fully-developed explanation for how the dialogue, narration, and verbal elements constitute fair use criticism: "The host's narration does not simply recount what is shown in Jukin's videos; instead the host makes comments about Jukin's videos that highlight their ridiculousness by creating fictionalized narratives of how the events transpired, using similes, or by directly mocking the depicted events and people." 97 In the next sentence of the opinion, the court acknowledges that "Equals Three's episodes also repeat portions of Jukin's videos multiple times within the same segment," 98 but the court does not follow this observation with an explanation as to how this purely visual element enhances the plaintiff's criticism. Graphics and costumes are similarly cited without any explanation for how these elements aid in the criticism. ${ }^{99}$ The contrast between the thorough explanation the court gives the video's spoken critical elements and the mere acknowledgementwith no comparable explanation - that the court gives to the visual critical elements exemplifies how courts considering audiovisual works as fair use criticism often frame their analysis. ${ }^{100}$

In short, courts that claim to consider the visual or filmic elements of an audiovisual work still often fail to provide any rationale or guidance as to which visual elements were deemed sufficiently recognizable critical elements, and which visual elements failed to be reasonably perceived as critical. This, in turn, means that litigants are unlikely to know which visual elements contributed to the court's analysis of their work as a piece of criticism under factor one of the fair use test.

\footnotetext{
96. Id. at 1105 (further finding that all but one of the Equals Three videos at issue were fair use).

97. Id. at 1104 (emphasis added).

98. Id.

99. Id.

100. See also Nat'l Ctr. for Jewish Film v. Riverside Films LLC, No. 5:12-CV-00044-ODW, 2012 WL 4052111, at *3 (C.D. Cal. Sept. 14, 2012) (finding that a documentary that used copyrighted film clips throughout its runtime incorporated "voiceovers, editing, and overall production" elements to add "[s]cholarly commentary" about the copyrighted film clips, but failing to clearly explain how the editing or overall production elements aided or enhanced the documentary's commentary); Estate of Barré v. Carter, 272 F. Supp. 3d 906, 932-33 (E.D. La. 2017) (finding that the use of audio clips from plaintiff's YouTube videos in Beyoncé's music video "Formation" were used solely to "create the tone, mood, [and] setting" for the music video, and thus were not fair use; but failing to explain how the visual elements of the "Formation" music video that accompany the audio clips factor into the court's analysis); Caner v. Autry, 16 F. Supp. 3d 689, 709-15 (W.D. Va. 2014) (finding that a series of YouTube videos that incorporate video clips from plaintiff's copyrighted speeches were used for the "transformative purpose" of "expos[ing] contradictions and dishonesty in the [plaintiff's] testimony," and were thus fair use; but stating the existence of defendant's transformative critical use in a conclusory manner and failing to discuss how any of the YouTube videos' visual or video elements impact the court's reasoning).
} 
Importantly, this also means that courts may fail to find a work of audiovisual criticism a transformative work under factor one, which then weighs against a finding of fair use. Beyond the litigants of a specific case, the courts' analytical silence regarding the visual and filmic elements of an audiovisual work of criticism means that future creators of audiovisual works will not be able to adequately use court opinions on fair use criticism to modulate their own behavior to avoid liability for copyright infringement.

\section{Aesthetic Nondiscrimination ANd CAMPBELL's Reasonable PerCEIVABILITY STANDARD}

One argument a court might make is that generalist judges simply do not possess the expertise or specialized skill to competently assess the format-specific nonspoken elements of a work of audiovisual criticism. Furthermore, some courts may feel that analyzing the non-spoken elements of an audiovisual work requires making normative aesthetic judgements about the work, in violation of Bleistein $v$. Donaldson Lithographing Co.'s invocation of the principle of aesthetic nondiscrimination. ${ }^{101}$ However, these arguments would be at odds with the reasoning in Campbell.

In Bleistein, Justice Holmes famously declared that "[i]t would be a dangerous undertaking for persons trained only to the law to constitute themselves final judges of the worth of pictorial illustrations, outside of the narrowest and most obvious limits." 102 This admonition has been commonly understood to stand for the principle of aesthetic nondiscrimination in copyright cases. ${ }^{103}$ The Supreme Court made clear in Campbell that the principle advanced by Justice Holmes in Bleistein extends to questions of transformativeness under factor one of the fair use test. ${ }^{104}$ According to the Court, the proper focus of the transformative use analysis for the song parody at issue was to assess whether or not the parodic character of the 2 Live Crew song could be reasonably perceived. ${ }^{105}$ The Court explained that once it concluded that the song's parodic character could be reasonably perceived, it would "not take the further step of evaluating its quality." 106 In making this declaration, the Campbell court demarcated the line between permissible — indeed, necessary-analysis of the existence of criticism in a work, and impermissible analysis of the merits of that criticism, disclaimed by Bleistein. Campbell thus counsels that conducting a thorough analysis of the existence of criticism in a work is not synonymous with making normative judgements about the success, quality, or value of the work's

101. 188 U.S. 239 (1903).

102. Id. at 251 .

103. See Robert A. Gorman, Copyright Courts and Aesthetic Judgments: Abuse or Necessity?, 25 COLUM. J.L. \& ARTS 1, 1 (2001).

104. See Brian L. Frye, Aesthetic Nondiscrimination \& Fair Use, 3 Belmont L. ReV. 29, 45 (2016) (explaining that, in Campbell, "the Supreme Court explicitly disclaimed any aesthetic element to the fair use analysis, citing Bleistein").

105. Campbell v. Acuff-Rose Music, Inc., 510 U.S. 569, 582 (1994).

106. Id. The Court then quoted Justice Holmes's famous words in Bleistein to explain this decision. Id. at $582-83$. 
critical elements. ${ }^{107}$ Though the work in Campbell was alleged to be a parody, subsequent courts have used Campbell's reasonable perceivability standard to analyze the transformativeness of a work more generally, even absent claims of parody or criticism. ${ }^{108}$

Despite the language of Bleistein, many legal scholars have commented on the contradictions inherent in its principle of aesthetic nondiscrimination and the frequency with which courts make aesthetic judgements while simultaneously invoking Bleistein. Robert Kirk Walker and Ben Depoorter argue that "the very types of subjective and qualitative assessments that Bleistein and its progeny sought to avoid are inextricable from copyright law."109 Walker and Depoorter further note that "when faced with questions that require qualitative evaluation of works of art, judges are forced to perform analytical jujitsu: first blocking with citation to Bleistein, then attacking with an ad hoc aesthetic theory of the court's own devising." 110 Keith Aoki has explained that "Bleistein demands aesthetic valueneutrality from the judiciary, yet simultaneously commands them to make valueladen decisions." "111 In the fair use context, Brian Soucek argues that "all four of the factors call for aesthetic judgment."112 Looking at the reasoning in Campbell, Robert Gorman has noted that he "count[s] at least four levels of aesthetic judgments" in Justice Souter's opinion even as it professes to follow Bleistein's aesthetic nondiscrimination principle. ${ }^{113}$ Other legal scholars have highlighted that the transformative use inquiry rests on a series of analytical premises that certain artistic fields, like contemporary art, have clearly rejected:

While some courts search for the artist's intent, contemporary art revels in the erasure of the artist; while other courts look for meaning in aesthetics, contemporary art rejects the assumption that art is even visual; while still other courts look for the viewpoint of

107. See MasterCard Int'l Inc. v. Nader 2000 Primary Comm., Inc., No. 00 CIV.6068(GBD), 2004 WL 434404, at *12-13 (S.D.N.Y. Mar. 8, 2004) (summarizing Campbell's requirements for parody under factor one of the fair use test thusly: "The message need not be popular nor agreed with. It may be subtle rather than obvious. It need only be reasonably perceived.").

108. See Cariou v. Prince, 714 F.3d 694, 707 (2d Cir. 2013) (rejecting plaintiff's contention that a court should assess how works may reasonably be perceived only in the parody context, explaining that "[n]o such rule exists"). See also Andy Warhol Found. for the Visual Arts, Inc. v. Goldsmith, 382 F. Supp. 3d 312, 326 (S.D.N.Y. 2019) (using the reasonable perceivability standard to assess the transformativeness of a work of art incorporating elements from a photograph); Oyewole v. Ora, $291 \mathrm{~F}$. Supp. 3d 422, 433 (S.D.N.Y. 2018) (same, to determine the transformativeness of a song lyric incorporated into in a new song).

109. Robert Kirk Walker \& Ben Depoorter, Unavoidable Aesthetic Judgments in Copyright Law: A Community of Practice Standard, 109 Nw. U. L. Rev. 343, 346 (2015).

110. Id. at 347 .

111. Keith Aoki, Contradiction and Context in American Copyright Law, 9 CARDOZO ARTS \& ENT. L.J. 303, 383 (1991).

112. Brian Soucek, Aesthetic Judgment in Law, 69 ALA. L. REV. 381, 431 (2017).

113. Gorman, supra note 103, at 18 (listing the four levels of aesthetic judgment as: (1) assessing whether plaintiffs "copied the "heart' of the Orbison song - clearly a musical value judgment"; (2) determining whether the copying was transformative; (3) assessing whether the transformative use was a parody or a satire, which "often requires considerable aesthetic or literary insight"; and (4) analyzing whether the parodist copied only the part of the work's heart necessary to conjure it up in a listener's mind, which "certainly requires making a most demanding psycho-aesthetic judgment"). 
"the reasonable observer," contemporary art pictures the notion of a stable or reasonable viewer as a fiction. ${ }^{114}$

Although there are forceful arguments that call into question whether or not an assessment of a work's transformativeness can ever be aesthetically neutral or reconcilable with Bleistein, the merits of these arguments are beyond the scope of this Note. It is sufficient for this Note's purposes to emphasize that, per Campbell, analyzing the reasonable perceivability of a work's critical elements is compatible with Bleistein, and Campbell remains good law. In order to conduct a complete analysis into whether or not a work's critical elements are reasonably perceivable, as Campbell instructs, a court must consider every element of a work wherein criticism might reasonably be contained. ${ }^{115}$ A court's hesitance to consider the visual or filmic elements of an audiovisual work when assessing the work as criticism under factor one is thus at odds with Campbell's reasonable perceivability standard.

The question then arises: What would a format-specific analysis of the nonspoken elements of an audiovisual work entail? The established jurisprudence in the appropriation art cases is instructive. In contrast to how courts typically treat works of audiovisual criticism, courts have shown a capacity and ability to assess the visual elements of a purely visual work in the appropriation art context.

\section{Court Analysis of Visual Elements in the Appropriation ART CASES}

In the art world, appropriation "refers to the act of borrowing or reusing existing elements within a new work." 116 Because appropriation artists take from pre-existing works to create their own art, alleged copyright infringement in works of appropriation art has become frequently litigated in the courts. ${ }^{117}$ Courts assessing appropriation art as fair use in these cases frequently engage in a visual analysis that incorporates the analytical tools associated with the visual arts field, suggesting, at minimum, that courts can become conversant in the language of visual analysis and incorporate format-specific analytical tools into their fair use analyses.

In Cariou v. Prince, the court was tasked with assessing whether or not art created by artist Richard Prince that "incorporated partial or whole images" from Patrick Cariou's photographs of Jamaican Rastafarians constituted fair use. ${ }^{118}$ The court began its opinion by acknowledging that appropriation art is an accepted art genre in the modern art world and commenting that Prince "is a leading exponent of this

114. Amy Adler, Fair Use and the Future of Art, 91 N.Y.U. L. REV. 559, 563-64 (2016).

115. See Campbell v. Acuff-Rose Music, Inc., 510 U.S. 569, 582 (1994) ("The threshold question when fair use is raised in defense of parody is whether a parodic character may reasonably be perceived.").

116. Hayley R. Rowe, Appropriation in Contemporary Art, 3 INQUIRIES J. 1 (2011), https://perma.cc/3ST8-ZLW9.

117. See, e.g., Cariou v. Prince, 714 F.3d 694 (2d Cir. 2013); Blanch v. Koons, 467 F.3d 244 (2d Cir. 2006); Graham v. Prince, 265 F. Supp. 3d 366, 381 (S.D.N.Y. 2017); Morris v. Guetta, No. LA CV1200684 JAK, 2013 WL 440127 (C.D. Cal. Feb. 4, 2013); Morris v. Young, 925 F. Supp. 2d 1078 (C.D. Cal. 2013).

118. Cariou, 714 F.3d at 699. 
genre."119 After establishing Prince's credentials and how he came to obtain copies of Cariou's work, the court commenced its analysis of fair use, starting with the first fair use factor. ${ }^{120}$ The court rooted its analysis of transformative use in the visual and aesthetic differences between the two works, explicitly articulating how the visual differences in the Prince work convey new meaning to an art audience:

These twenty-five of Prince's artworks manifest an entirely different aesthetic from Cariou's photographs. Where Cariou's serene and deliberately composed portraits and landscape photographs depict the natural beauty of Rastafarians and their surrounding environs, Prince's crude and jarring works, on the other hand, are hectic and provocative. Cariou's black-and-white photographs were printed in a $91 / 2$ " x 12 " book. Prince has created collages on canvas that incorporate color, feature distorted human and other forms and settings, and measure between ten and nearly a hundred times the size of the photographs. Prince's composition, presentation, scale, color palette, and media are fundamentally different and new compared to the photographs, as is the expressive nature of Prince's work. ${ }^{121}$

After engaging in its analysis of the works' visual elements, the court concluded that Prince's works "have a different character, give Cariou's photographs a new expression, and employ new aesthetics with creative and communicative results distinct from Cariou's." 122

In Cariou, the court used the interpretive tools of visual art analysis-looking at Prince's "composition, presentation, scale, color palette, and media" 123 - to make its assessment about the overall message, and thus the degree of transformativeness, of Prince's works. It did so by recognizing that composition, form, and color are meaning-generating elements that Prince specifically used to convey something new to the viewer. ${ }^{124}$ The court contrasts the "deliberately composed" photographs by Cariou with Prince's "hectic and provocative" collages that "feature distorted human and other forms." 125 Here, the court articulates an analysis that ties color and form with the underlying emotional message of the Prince collages, finding, in essence, that these visual elements are imbued with meaning and that a reasonable observer could ascertain that meaning from the visual elements alone. The court's analysis in Cariou is analogous to a visual art analysis one might encounter in an art history class or an article of art criticism. ${ }^{126}$

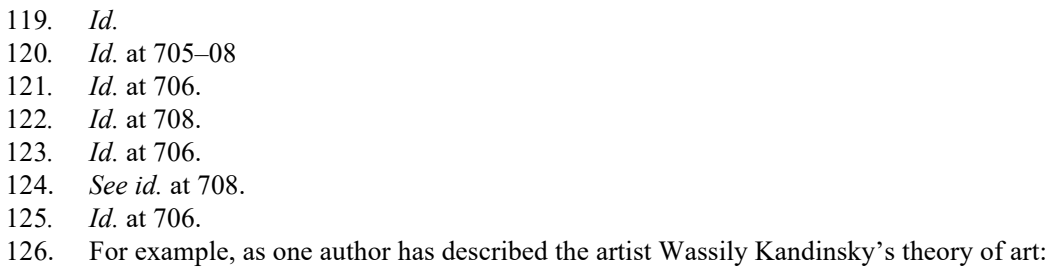

Art is not a matter of the outward imitation of nature. Art has, on the one hand, its own autonomous language, which follows (or should follow) its own formal laws.... [A] rt's mission is not to simply imitate nature, but to represent its inner sound or color, in short its mood. Not the depicted object itself is important but its emotional or symbolic value: that which it awakens or evokes in us. 
Importantly, the Cariou court did not concern itself with whether or not Richard Prince's artwork was a worthwhile addition to modern art, nor did it consider whether or not the use of Cariou's portraits in the Prince works enhanced the aesthetic merit of the works. It simply assessed whether or not Prince's use of the Cariou portraits was sufficiently transformative under factor one of the fair use test. To answer that question, the court undertook an analysis of the visual elements of the works where transformativeness might be reasonably perceived. Although the court articulated a type of visual art analysis to explain how the transformative qualities of Prince's works could be reasonably perceived by an art audience, it did not attach normative aesthetic judgements to this analysis or imply that the transformative elements make Prince's works good art. Rather, the court's visual art analysis was solely in service of answering the question of whether or not the transformative character of Prince's works could be reasonably perceived. Once the court concluded that it could be perceived, the inquiry moved on to the other fair use factors.

In other cases involving appropriation art, courts have used a similar mode of analysis to find transformative use under factor one of the fair use test. In a case involving Jeff Koons's use of a copyrighted magazine ad in his painting "Niagara," the court cited the "changes of its colors, the background against which it is portrayed, the medium, the size of the objects pictured, the objects' details and, crucially, their entirely different purpose and meaning" as evidence that Koons's use was transformative. ${ }^{127}$ Similarly, in a more recent case involving Richard Prince's use of Donald Graham's photograph in Prince's "New Portraits" print series, the court emphasized the mere "de minimis cropping" of Graham's photograph and the lack of "aesthetic alterations" to the photograph in Prince's work, contrasting the work at issue with the creative changes made to the works in Blanch and Cariou. ${ }^{128}$ The court went on to suggest that since Prince's use was not transformative as a matter of law, Prince could choose to submit articles of art criticism to the court as evidentiary support for the proposition his work is, in fact, transformative. ${ }^{129}$

The judicial opinions in the appropriation art cases reveal, at minimum, that judges are able to develop an understanding of the analytical and interpretive tools used within a specific artistic field and utilize those interpretive tools in making fair use determinations. These opinions also establish that undertaking a format-specific analysis of the visual, filmic, or non-spoken elements of a given work to assess its transformativeness does not require courts to make normative aesthetic judgements about a work. As shown above, this type of analysis does not contravene Bleistein, and it is endorsed by the Court in Campbell and the appropriation art cases. Yet, courts thus far have been hesitant to engage with the non-spoken elements of reaction

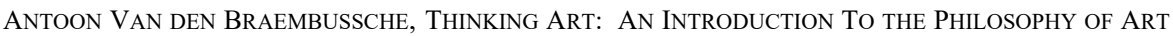
103-04 (2009). For a general discussion of how artists use visual forms to convey meaning, see LORENZ EITNER, INTRODUCTION TO ART: AN ILlustrated TOPICAL MANUAL 38-45 (1966) (explaining that elements like line, shape, and color, are the "signs through which artists realize ideas and express feelings" and calling these forms "the vocabulary of art").

127. Blanch v. Koons, 467 F.3d 244, 253 (2d Cir. 2006).

128. Graham v. Prince, 265 F. Supp. 3d 366, 381 (S.D.N.Y. 2017).

129. Id. at 382 . 
videos and other works of audiovisual criticism when these cases come before the courts. Why? A likely answer is that judges need some analytical framework in which to anchor their analysis of a creative work, and without specific knowledge of the interpretive tools of a particular creative format, they default to modes of analysis more familiar to the judge or more developed in the case law. The remainder of this Note attempts to address this problem.

In Part III below, this Note relies on a few key film studies concepts to explore ways in which filmmakers manipulate specific visual and filmic elements to generate meaning and enhance their film's message. Part III then illustrates ways in which a court could analyze the visual or filmic elements of a YouTube reaction video or other audiovisual work to more comprehensively assess the work's critical content, or lack thereof.

\section{TOWARDS A MORE ENCOMPASSING CRITICISM STANDARD: LESSONS FROM FILM STUDIES}

The development of film and the motion picture in the early twentieth century allowed artists and directors to push the boundaries of art into a new dynamic medium, utilizing the uniqueness of the audiovisual form to tell stories in novel and creative ways. ${ }^{130}$ Some of the key features of film as an art form are its ability to utilize the projection of movement, the frame of the camera, the order and selection of shots, and the frequency of the cut to enhance the underlying story. ${ }^{131}$ Many of these visual elements were already known to painters, photographers, and visual artists, but the film camera allowed filmmakers to utilize these elements over time, manipulating them throughout the course of a film's runtime. ${ }^{132}$ These visual and

130. One theorist summarizes the unique impact of film as a medium thusly:

First, cinema can generate a more immediate and visceral response than can novels, and this is in part due to the fact that it can produce the startle response and novels cannot, which in turn is grounded on the capacity of moving pictures, music and sound effects to be spontaneously interpreted as threatening, whereas the same is not true of the sensory input associated with novels. Second, photographs are prone to have a greater emotional impact than paintings, because photographs can seem as if they were transparent and have more evidential warrant than do paintings. Third, camera movement and editing can be used to create emotional impact, perhaps generating a rising sense of excitement by increasing editing rhythm, and this rests on the fact that cinema is composed of multiple pictures; so the same mechanisms are not available in literature. Fourth, the fact that non-interactive films have a work time conditions the emotional control that filmmakers can exert over their audience. Performances (which are themselves sometimes artworks, as well as being of artworks) have a work time, but works in other media, such as painting and literature, do not, and consequently cannot control the timing of the flow of emotions so precisely. Fifth, sound film, unlike literature, can have a musical track and music in film is central to its emotional impact, achieving greater emotional precision through its associations with words and images.

Berys GAuT, A PHILOSOPHY OF Cinematic ART 299 (2010).

131. See generally Ken DANCYGER, StORYTELling FOR FILM AND TEleViSION: From FiRST WORD TO LAST FRAME 105-18 (2019) (outlining the editing tools filmmakers utilize to advance the film's story and construct a compelling work).

132. Indeed, after the advent of the film camera, early film theorists recognized that "cinema possessed unique capacities as a medium of time and space" and the film camera was a unique technology 
filmic elements were not seen by filmmakers as constraints of the audiovisual form, but rather vital elements that both "propel the storyline" and "act as metaphor to denote and convey a deeper narrative meaning, one that operates beyond what any particular dialogue can articulate or relate." 133

As an audiovisual format, YouTube reaction videos and other forms of online video criticism manipulate the same visual and filmic elements inherent to film as a way to convey their criticism and impart additional meaning to the audience. As such, courts can use analytical tools common to film studies to more accurately and holistically analyze audiovisual works for critical elements specific to the audiovisual form. By incorporating a film-specific analysis in cases involving reaction videos or other audiovisual criticism, courts will be able to more easily recognize and analyze the transformative critical content in a particular work of audiovisual criticism. Thus, legitimate works of audiovisual criticism will be more likely to receive the same fair use protection courts give to textual and spoken criticism.

This Note offers two ways in which the analytical tools of film studies can be embraced in future fair use criticism jurisprudence to more accurately and completely assess the critical content of an alleged work of audiovisual criticism. First, this Note explores the concept of the cut and how filmmakers utilize editing to convey meaning to the audience. Then, this Note explores the concept of framing and how filmmakers use the composition of a particular shot, as well as camera movement, to convey meaning to an audience. The film studies concepts introduced in Part III are illustrative, not exhaustive; courts are encouraged to actively seek out film studies textbooks and other materials as necessary to familiarize themselves with the range of visual techniques creators of audiovisual works utilize to convey meaning to an audience.

\section{A. Editing AND The Cut}

In filmmaking, the selection of the individual shots that comprise the film is "a matter of active decision-making - the product of human choice."134 Filmmakers and editors actively decide which shot will follow the next, and in the process, they create a continuous string of individual shots that make up a particular scene. Editing, also called cutting, is "the method[] by which filmmakers link individual shots to one another." 135 The cut, then, is simply the transition in film "from one shot to another." 136

By cutting from shot to shot, filmmakers create meaning and association through shot juxtaposition that would not otherwise exist when viewing any one shot in

\footnotetext{
that allowed filmmakers "to collapse conventional boundaries of time and space" within a unified work. Charlie Keil, EARly American Cinema in Transition: Story, STYle, and Filmmaking, 19071913, at 84 (2001).

133. MARK DE VALK \& SARAH ARNOLD, THE FILM HANDBOOK 10 (2013).

134. ED SiKov, FiLM STUdies: AN INTRODUCTION 57 (2010).

135. Id.

136. Id.
} 
isolation. Because "juxtaposition is inherently associative," 137 film audiences are primed to associate the shot before a cut with the shot after a cut. Thus, filmmakers can manipulate the order and structure of shots to convey narrative meaning to the audience. ${ }^{138}$ Editing, then, is meaning-generating; it "foregrounds states of mind that the dialogue may not address directly ... [and] control[s] the release of new story information so that earlier story developments are closed off, and new lines open up, driving the narrative into the next scene."139

In film studies, the theory that there is a relationship between the cut and narrative meaning is often traced back to Lev Kuleshov, a post-revolution Soviet era filmmaker and theorist. Kuleshov is said to have conducted editing experiments with film montage that helped establish that "cinematic meaning is a function of the ordering of shots." 140 In his classic experiment, Kuleshov played for an audience the exact same shot of an actor's "expressionless face followed by shots of a bowl of soup, a child in a coffin, and a sunny landscape. The audience applauded the subtle variations of [the actor's] face to show alternately hunger, pity, and joy."141 Kuleshov saw his experiment as evidence that "the meaning of a film sequence was a product of its cutting." 142 Today, the effect that the pairing of individual shots in a sequence has on the generation of narrative meaning in film is known as the Kuleshov effect. ${ }^{143}$

Kuleshov's experiments were embraced by fellow Soviet filmmaker and film theorist Sergei Eisenstein. Eisenstein built upon the idea of the Kuleshov effect, believing that the juxtaposition of shots should not be conceived of as a pairing of shots, but as a collision. ${ }^{144}$ Eisenstein believed that "the rapid juxtaposition of ... two sets of images through fast editing causes a collision that in turn creates a third set of images (construed in the spectator's mind)." ${ }^{145}$ Under Eisenstein's theory of montage, there is, in essence, a "dialectic relationship between each shot," provoking the audience to "produc[e] meaning through the interpretation of the montage." 146

137. John Preston Isenhour, The Effects of Context and Order in Film Editing, 23 AV COMM. REV. 69, 79 (1975).

138. One film theorist compares the relationship between the meaning of individual shots and the meaning of a scene as a whole to the relationship between individual words and a whole poem. See Bill R. Scalia, Toward a Semiotics of Poetry and Film: Meaning-Making and Extra-Linguistic Signification, 40 LiTERATURE/FILM Q. 46, 52 (2012) ("While a long poem may have many stanzas and many matrices with corresponding ... words, so the film's complete unit of significance may be completed scenes or sequences, 'meaning units' of film that complete an idea contained in a shot or arrangement of shots and move the film from one sequence to the next.").

139. Michael Frierson, Film and Video Editing TheOry: How Editing Creates Meaning 105 (2018).

140. Stephen Prince \& Wayne E. Hensley, The Kuleshov Effect: Recreating the Classic Experiment, 31 CINEMA J. 59, 59 (1992).

141. Steven Kovacs, Kuleshov's Aesthetics, 29 FiLm Q. 34, 34 (1976).

142. Prince \& Hensley, supra note 140, at 62.

143. For more discussion about the Kuleshov Effect in modern cinema, including a recreation of the famous experiment, see Folding Ideas, The Kuleshov Effect, YOUTUBE (Jan. 14, 2017), https://perma.cc/M9G6-G82S.

144. DE VALK \& ARNOLD, supra note 133, at 126.

145. Susan Hayward, Cinema Studies: THe Key ConCEPTS 137 (5th ed. 2018).

146. DE VALK \& ARNOLD, supra note 133, at 126. 
Although Eisenstein's use of montage was largely to "agitate the audience into action through propaganda" and Soviet political messaging, filmmakers today recognize that they can utilize Eisenstein's theories of montage to provoke an audience response that aids the film's narrative or compels the audience to make thematic connections. ${ }^{147}$

One prominent example of the meaning-generating effect that editing has on a filmed sequence can be found in the Orson Welles classic, Citizen Kane. ${ }^{148}$ After young Charles Foster Kane is first sent away by his parents to live with the banker Walter Thatcher, the film lingers on a shot of Kane's sled being slowly covered with snow from a snowstorm. ${ }^{149}$ The film then cuts to young Kane underneath a Christmas tree as Thatcher looms over him, opening a present containing a new sled. In the span of a few seconds, the film next cuts to a scene many years in the future as Thatcher dictates a letter to the now twenty-five-year-old Kane, outlining the details of Kane's vast fortune. In isolation, the shot of the sled being covered with snow may simply evoke the passage of time, while the shot of Kane opening a new sled may evoke the experience of a child at Christmas. However, the juxtaposition of these two shots generates an entirely new meaning, one that is not perceivable from viewing either shot in isolation. When juxtaposed, these two shots evoke Kane's transition from the naïve innocence of childhood into a capitalist, but also isolating, world of wealth and excess. The old sled, likely a gift from his parents, lays unused and forgotten, while Kane-now far removed from his family-receives a brand-new sled, a symbol of the wealth and money that will soon dominate Kane's life. This is further underscored by the film's quick cut from young Kane opening the new sled to, years later, Thatcher writing a letter listing all of the holdings and wealth over which now-adult Kane has ownership. The scene jumps from young Kane to adult Kane in mere seconds, and this editing choice helps signal to the audience what is happening to Kane as a character: Kane lost his childhood in an instant and was forced to grow up quickly. ${ }^{150}$

Similarly, when analyzing audiovisual works for critical content, courts can incorporate an assessment of the work's cuts and editing to uncover additional critical meaning that the work's creator intended to convey to the audience. Just as filmmakers use editing and shot selection to convey narrative meaning, creators of reaction videos and other audiovisual works of criticism use these same visual elements to convey critical meaning. Re-examining one of the YouTube reaction videos in dispute in the Equals Three case provides a helpful illustration of this principle.

In one of the disputed Equals Three videos, entitled "Blazing Crow," commentators Keegan Michael-Key and Jordan Peele play a copyrighted clip of a teenager performing a skilled maneuver in a game of dodgeball and tagging out the

147. Id. at 124, 132-34 (listing The Godfather, My Winnipeg, and Requiem for a Dream as movies that use Eisenstein-like montage to convey narrative meaning).

148. Citizen Kane (Mercury Productions 1941).

149. Id. (at 22:55 of the movie).

150. The author apologizes for any spoilers that occur in this Note's description of the plot of Citizen Kane. 
opposing player. The video then cuts to Key and Peele running around the studio, flailing their arms above their heads, and shouting indiscriminately. ${ }^{151}$ If an analysis of the criticism and commentary contained in this part of the video were confined solely to the words spoken by Key and Peele, it is unlikely that a court would interpret indiscriminate shouting as sufficiently articulated criticism or commentary. However, the quick cut from the dodgeball video to Key and Peele's excited actions and movements create a commentary-specific purpose that is likely recognizable to the average viewer. Simply put, Key and Peele's reaction evokes amazement at the skills of the dodgeball player and mocking derision of the other player who was tagged out. Their reaction mimics the type of boastful taunting that the winning side of a dodgeball game might levy against the losing side after winning a match. The fact that the reaction video cuts to Key and Peele immediately after the opposing dodgeball player is tagged out emphasizes the focus of their criticism through the visual pairing of the two shots: a schoolyard taunting of the dodgeball player who was tagged out. ${ }^{152}$

There are many other conceivable contexts in which a reaction video might utilize editing as a tool through which to generate critical commentary. One can imagine a reaction video wherein a clip of a mediocre talent show contestant's performance cuts to a clip of crickets chirping in a field. Another reaction video might feature a particularly incoherent scene from the latest sci-fi blockbuster that then cuts to a clip of a garbage dumpster on fire. In these instances, critical commentary is communicated to the audience solely through the visual juxtaposition and symbolic interplay between the two shots. By attuning itself to the visual nature of the reaction video and the meaning-generating role that editing plays in the audiovisual form generally, a court can more accurately and adequately analyze alleged works of audiovisual criticism for critical content under factor one of the fair use test.

\section{B. Framing, Composition, and Camera Movement}

The frame of a shot and the manipulation of visual elements within the frame constitute additional visual elements of film that filmmakers use to imbue their works with meaning. In film, the frame "describes the borders of the image onscreen-the

151. Ray William Johnson, BLAZING CROW - Key \& Peele (2012), YouTuBE (Oct. 9, 2012), https://perma.cc/76KJ-C375 (at 00:36 of the video).

152. Even if a court found that the editing furthered the video's criticism, it does not mean that the video would be sufficiently transformative to weigh in favor of fair use under factor one, nor does it mean that the video would ultimately be found to be fair use. Under factor one, the court would have to consider the extent and purpose of the criticism to determine if the criticism contained therein "adds something new, with a further purpose or different character, altering the first with new expression, meaning, or message." Campbell v. Acuff-Rose Music, Inc., 510 U.S. 569, 579 (1994). Then, even if it found that factor one weighs in favor of a finding of fair use, it would have to balance the first factor with the other fair use factors to determine whether the use is ultimately fair. Id. at 569. In cases like this one, where the criticism conveyed through the editing is supplemented with spoken criticism targeting the clip later in the reaction video, an analysis of the critical elements contained in the editing helps bolster a court's finding that the criticism is reasonably perceivable under factor one. However, criticism conveyed through editing alone can still constitute a sufficiently transformative use under factor one. See infra Part IV. 
rectangular frame of darkness on the screen that defines the edge of the image." ${ }^{153}$ All action in a film takes place within the frame. The arrangement of all elements within a frame - - "settings, props, lighting, costumes, ... actors, their gestures, and their facial expressions," as well as "the camera's actions and angles and the cinematography" - constitutes the mise-en-scène. ${ }^{154}$ The mise-en-scène is thus "the totality of expressive content within the image." 155

Filmmakers manipulate the composition of elements within a frame to convey narrative information to the audience. Part of what distinguishes a filmmaker's use of the frame from a painter's use of the frame is that the film's frame is dynamic and ever-moving. According to one film theorist, "[b]ecause the views within the frame are perpetually changing, perpetually shifting, the frame's organization of those views is perpetually in the process of making new significations .... The film frame is perpetually signifying new meanings in new ways throughout a film."156 A character may be framed to signify their power and strength in one moment and their weakness and despair in the next. Elements like shot selection, camera angle, and camera movement help filmmakers convey this meaning.

Camera movement and shot selection are an integral part of the frame's mise-enscène. According to film theorist Vivian Sobchack, "movement is at the heart of cinematic meaning." 157 Common forms of movement within a film frame include the pan ("when the camera itself is stationary but pivots on its axis from side to side"), the tilt (when "the camera is stationary but tilts up and down"), and the zoom (when the "camera operator creates the impression of movement by shifting the focal length of the lens from wide angle to telephoto or from telephoto to wide angle, but the camera itself does not move"). ${ }^{158}$ These movements generate visual forms that are invested with narrative meaning, as essential to the film's storytelling as the screenwriter's dialogue or the actor's performance. For example, because a zoomin shot "picks out and isolates a person or object," the shot is used to place emphasis on a specific element within the frame. ${ }^{159}$ One theorist has gone so far as to call the zoom, in particular, "a very expressive thought, sometimes searching and finding, sometimes receding and denying, sometimes questioning and inquisitive." 160

Shot selection plays an additional role in a filmmaker's generation of meaning. A scene with a character framed by a high angle shot "tend[s] to result in a sense of subservience and weakness," while low angle shots "typically give the character dominance, authority, superiority, and strength." 161 A shot of a character in extreme close-up, for example, conveys a feeling of "being in someone's personal and emotional space," while a wide shot conveys "the least intimacy between the

153. SIKOV, supra note 134 , at 18 .

154. Id. at 5-6 (emphasis omitted).

155. Id. at 6 (emphasis omitted).

156. Gerald Mast, On Framing, 11 CRITICAL INQUIRY 82, 85 (1984).

157. DANIEL FrAMPTON, FILMOSOPHY 44 (2012).

158. SIKOV, supra note 134, at 25, 27 (emphases omitted).

159. HAYWARD, supra note 145, at 526.

160. FRAMPTON, supra note 157 , at 45.

161. Kurt LANCASTER, BASIC CINEMATOGRAPHY: A CREATIVE GuIDE TO VisuAl StORYTELLING $62(2019)$. 
characters" in the shot. ${ }^{162}$ A point-of-view ("POV") shot is a type of shot taken from the height and angle of a character in the scene, "creating the sense that we the viewers are seeing what the character is looking at."163 Thus, with a POV shot, the filmmaker may well be inviting the audience to step into the mind of the character and view the world through the character's subjective worldview. ${ }^{164}$

Citizen Kane again provides an example of how composition within the frame and camera movement can be manipulated to add meaning to a film. Late in the movie, there is a scene between Kane and his wife, Susan, in the large empty living room of their palatial Xanadu mansion. ${ }^{165}$ Welles frames the scene so that Kane is seated far across the room from Susan, who is crouched on the floor completing a jigsaw puzzle. The distance between the two characters is much further than the normal distance most people keep while conversing, requiring Kane and Susan to yell to one another across the vast, empty expanse. This deliberate framing choice mirrors visually what the two characters are feeling internally; Susan feels isolated from her friends and city life, and Kane feels isolated from both Susan and the world at large. In a later scene, as Kane trashes Susan's room after she leaves him, the camera moves quickly and shakily as it follows Kane across the room flipping tables, ripping apart curtains, and shattering glass ornaments. ${ }^{166}$ Here, the jerkiness of the camera movement amplifies the internal turmoil and strife Kane is feeling over Susan's departure. Through the camera's movement, Welles communicates the hectic state of Kane's inner life to the audience, even as Kane remains silent throughout the room-trashing scene. ${ }^{167}$

Courts assessing works of audiovisual criticism for transformativeness under factor one of the fair use test should more fully incorporate an analysis of these filmic elements in their underlying assessment of the critical work. While narrative film utilizes framing, composition, and camera movement to convey meaning to the audience that enhances the story, works of audiovisual criticism utilize these same

162. Id. at 59

163. DAISUKE MiYAO, Cinema Is A CAT 60 (2019).

164. Related to this idea is the concept of gaze. Filmmakers sometimes utilize the movement of the camera to invite the viewer to look upon, or gaze at, various characters or elements within the frame. In her seminal paper "Visual Pleasure and Narrative Cinema," feminist theorist Laura Mulvey posited the concept of the "male gaze," arguing that "[t]he cinema satisfies a primordial wish for pleasurable looking," and in the Hollywood studio system in particular, the camera has been used as a means to codify male desire, "highlighting a woman's to-be-looked-at-ness" and "build[ing] the way she is to be looked at into the spectacle itself." Laura Mulvey, Visual Pleasure and Narrative Cinema, 16 SCREEN 6, 9, 17 (1975).

165. CITIZEN KANE, supra note 148 (at 1:40:40 of the movie).

166. Id. (at $1: 48: 25$ of the movie).

167. Another example of the way in which camera movement conveys meaning to the audience can be found in the Buster Keaton film, SHERLOCK JR. (Metro Pictures Corp. 1924). In Sherlock Jr., "[t]he protagonist is an aspiring detective who reads a guidebook advising him to trail the primary suspect. Taking the advice very literally, he walks one step behind the suspect for several yards. When the suspect stops to pick up a cigarette, Keaton pulls up just in time - and the camera halts briefly to keep them in frame. When they start moving again, so, too, does the camera. The humor of the scene arises from the incongruity between the story situation of two characters who cannot predict each other's actions and the performance of two actors whose movements appear to be in perfect synchronization-with each other and with the camera." PATrick KeAting, The DynAmiC Frame: CAMERA Movement in ClassiCAL HOLLYWOOD 22-23 (2019). 
filmic elements to communicate or emphasize their critical content. By overlooking the role these elements play in conveying critical meaning, courts run the risk of under-identifying works of criticism that are sufficiently transformative under factor one. In a reaction video, for instance, critics can both manipulate their own composition within the frame and re-compose the frame of the underlying copyrighted work to draw viewer attention towards the elements of the video they are criticizing.

In the reaction videos at issue in Equals Three, the video editors repeatedly use composition and camera movement to sharpen their critical commentary and create additional critical meaning. In the video "Drunk Babies," the commentator critiques a copyrighted clip of a groom dropping his bride while walking down a concrete sidewalk. ${ }^{168}$ Towards the end of the clip, a wedding attendee rushes to help the couple, throwing aside a drink in the process. The commentator replays the same sequence, zooming into the clip of the wedding attendee so that the throwing of the drink is displayed in the center of the frame. By re-composing the underlying shot so that the drink throw takes up the majority of the frame, the commentator highlights the absurdity of the clip at issue. He refers to the attendee as a "great friend" for throwing away his drink to help, while the zoomed-in footage of the drink throw plays repeatedly. Through this framing choice, the commentator's criticism becomes clear: He thinks the spilling of the drink on the sidewalk is more worth lamenting than the potential injuries of the groom and bride. ${ }^{169}$

An analysis of the framing and composition of another video at issue in Equals Three, "Sheep to the Balls," reveals additional critical meaning that the court was unable to find in the commentator's dialogue alone. ${ }^{170}$ Of the eighteen reaction videos at issue in Equals Three, the court found that a single video, "Sheep to the Balls," failed to "add something new to Jukin's videos" sufficient to render it transformative under factor one of the fair use test. ${ }^{171}$ The copyrighted Jukin clip used in the Equals Three video is a news segment featuring "the first person to buy an iPhone 6 in Perth dropping the phone." ${ }^{\prime 72}$ The court explained that this video is insufficiently transformative because Equals Three's admitted purpose for using the Jukin video clip was to make "two general, broad points that were not directly aimed at criticizing or commenting on the video." 173 As the court explained, the two general points Equals Three claimed to be making with its commentary are: (1) to implore

168. Ray William Johnson, Drunk Babies, YouTUBE (Nov. 7, 2014), https://perma.cc/HV4F-XTDU (at $00: 17$ of the video).

169. The court's analysis of the "Drunk Babies" video explains that the video "shows the footage of the actual trip and fall multiple times with different graphics and commentary interspersed," and then excerpts quotations from the commentator about the Jukin video. Equals Three, LLC v. Jukin Media, Inc., 139 F. Supp. 3d 1094, 1105 (C.D. Cal. 2015). However, despite referencing graphics and editing, the court does not explain how the graphics or other visual elements specifically comment on or critique the Jukin video. See supra Part II.B.

170. Ray William Johnson, Sheep to the Balls, YouTuBE (Sept. 23, 2014), https://perma.cc/E9382KSS (at 01:45 of the video).

171. Equals Three, 139 F. Supp. 3d at 1105.

172. Id.

173. Id. 
viewers to not "be first at shit"; and (2) to show how "Apple, Inc.'s method of packaging iPhones at the top of the box is absurd."174 Yet, while the commentator's words alone may only articulate these general points, Equals Three also re-composes the frame of the Jukin video clip and manipulates the video playback speed in ways that likely convey at least some critical meaning to the audience.

Specifically, Equals Three dramatically zooms into the Jukin video, re-framing the video such that the young iPhone purchaser's hands opening the phone box take up the majority of the frame. This zoomed-in shot telegraphs to the audience the import of the iPhone box in the purchaser's hand and signals that Equals Three wants the audience to focus on this part of the Jukin video to the exclusion of other peripheral elements. Equals Three also slows down the playback speed of the Jukin video, which serves to amplify and emphasize the shakiness of the purchaser's hands as he opens the box. Lastly, Equals Three frames the entirety of the Jukin video at a slightly tilted, off-center angle within the frame of its own video, thus creating an additional visual sense of instability and impending collapse. In total, these elements may communicate to the audience that the iPhone purchaser was clumsy and careless when opening the box. While the visual derision of the purchaser's clumsiness may still not be enough to render the video a transformative work of criticism under factor one, it is nonetheless a conceivable critical element directly targeting the Jukin video. ${ }^{175}$ If the Equals Three court had analyzed and addressed these visual elements in its opinion, the court would have - at the very least - provided the parties with a more encompassing, holistic analysis of how each element in the Equals Three video contributed to its ultimate determination of the video's transformativeness.

In short, because film is an inherently visual medium, the discrete visual elements of a film make up the language of film; these visual elements are essential components that communicate the film's overall purpose and theme. Under one conception of film language advanced by film theorist Christian Metz, "repeated film consumption has led to audiences acquiring a 'learned' ability to understand cinematic language construction.... Thus, it can be argued that film grammar functions .... as a means to create, articulate, and impart a knowledge of the filmmaker's intentions and ideas." "176 Put another way, the composition of a shot or the movement of the camera have become meaning-generating elements of film that can be analyzed just like the prose of a novel. This film language has analogous application in non-narrative audiovisual works like YouTube reaction videos or the video essay. Creators of audiovisual criticism expect audiences to be familiar with

174. Id.

175. It should also be noted that the commentator reacts to the Jukin video by exclaiming "that's embarrassing" and commenting that the purchaser looks "nervous," "has to jiggle the box a lot to even get it open," and "is holding the box at an angle." Ray William Johnson, supra note 170 (at 02:05 of the video). These comments are presumably references to the purchaser's clumsiness, meant to criticize the manner in which the purchaser chose to open the box. Although the court likely considered these comments when making its analysis, it does not refer to them in the final opinion. See Equals Three, 139 F. Supp. 3d at 1105.

176. Discussed in DE VALK \& ARNOLD, supra note 133, at 8 (emphases omitted). For more of Metz's theory of film and language, see generally CHRistian METZ, FILM LANGUAGE: A SEMIOTICS OF THE CINEMA (1991). 
the basic language of film, utilizing filmic elements like shot selection or camera movement to convey critical meaning to the audience. The more familiarized that courts are with the elements of film, the more courts will be able to analyze audiovisual works on their own terms and identify the role these filmic elements play in the work's overall purpose. This, in turn, allows courts to conduct a more thorough, searching fair use analysis of works of audiovisual criticism.

\section{CASE STUDY: EDITING AS CRITICAL COMMENTARY IN HUGHES V. BENJAMIN}

The importance of analyzing the visual elements of an alleged work of audiovisual criticism for fair use purposes can be further elucidated by considering a real-life example of a YouTube video that contains no original spoken commentary. The case study below illustrates how courts can use a close analysis of the editing of an alleged work of audiovisual criticism to find reasonably perceivable critical elements that are not present in the work's dialogue alone.

In a federal district court case decided in February 2020, YouTube content creator Akilah Hughes sued fellow YouTube content creator Carl Benjamin for copyright infringement, alleging that Benjamin copied clips from her YouTube video "We Thought She Would Win" and posted them publicly on his own YouTube channel and social media accounts. ${ }^{177}$ Hughes is a writer, activist, and comedian who posts political commentary and humor videos on her YouTube channel, Akilah Obviously. ${ }^{178}$ Benjamin has been described as a conspiracy theorist and a member of the far right, ${ }^{179}$ and he runs a YouTube channel where he posts polemical videos "speaking out against movements for gender equality," racial diversity, and feminism, and attacking other politically liberal causes. ${ }^{180}$ Benjamin is hardly a sympathetic plaintiff: He has been criticized for peddling in "rank misogyny" and racism, ${ }^{181}$ and his videos have been called "odious" and "normatively objectionable." 182

In November 2016, Hughes posted the video "We Thought She Would Win" to her YouTube channel: a nine minute video in which Hughes documents her experiences during Hillary Clinton's 2016 election night party at the Javits Convention Center and expresses her disappointment that Clinton lost the 2016

177. Hughes v. Benjamin, 437 F. Supp. 3d 382 (S.D.N.Y. 2020).

178. See Akilah Hughes, About Me, IT's AKILAH, OBVIOUSLY!, https://perma.cc/T7FA-BZBG (last visited Nov. 3, 2020).

179. See Jane Dalton, Carl Benjamin: Milkshake Thrown at Ukip Candidate for Fourth Time This Week, INDEPENDENT (May 19, 2019), https://perma.cc/VCT4-D3ZV; David Gilbert, Crowdfunding Site Patreon Is Purging Far-Right Figures, VICE (Dec. 7, 2018), https://perma.cc/5TM3-L4VG; Rajeev Syal, Police Investigate Ukip Candidate over Jess Phillips Rape Comments, GUARDIAN (May 7, 2019), https://perma.cc/C7HF-5JY4.

180. Nellie Bowles, Patreon Bars Anti-Feminist for Racist Speech, Inciting Revolt, N.Y. TIMES (Dec. 24, 2018), https://perma.cc/RH63-TGGM.

181. Keza MacDonald, We've Seen Carl Benjamin's Rank Misogyny Before-Remember Gamergate?, GUARDIAN (May 9, 2019), https://perma.cc/LVT3-YS68; Bowles, supra note 180.

182. Eric Goldman, Video Excerpts Qualify as Fair Use (and Another 512(f) Claim Fails)—Hughes v. Benjamin, TECH. \& MKTG. L. BlOG (Feb. 5, 2020), https://perma.cc/SKT8-FMNV. 
presidential election. ${ }^{183}$ Shortly after Hughes posted her video, Benjamin took various clips from "We Thought She Would Win" and selectively edited the clips to create a new video, entitled "SJW Levels of Awareness," in which Benjamin juxtaposes Hughes's statements from various parts of her original video. ${ }^{184}$ The Benjamin video does not include any original dialogue, "commentary or video recorded by Benjamin." 185 Instead, the entirety of the Benjamin video consists of selected clips from Hughes's original video in which she comments on the 2016 election. ${ }^{186}$ Benjamin claimed his use of the Hughes video was a parody, and thus fair use. ${ }^{187}$

In her Complaint, Hughes alleged that the Benjamin video "provides no additional content, commentary, or criticism of the Copyrighted Work, its contents, or Hughes, and contains no additional expression whatsoever; it is a bare, retitled compilation of clips of the Copyrighted Work." 188 In subsequent court filings, Benjamin contended his video is critical in nature, characterizing his work as "an attempt to discredit [plaintiff] and her political positions" and "to mock ... Hughes's lack of awareness." 189 Specifically, Benjamin claims to have achieved his intended criticism through "skillful video editing." 190

The court proceeded to analyze the Benjamin video under each of the fair use factors, ultimately holding that the Benjamin video was fair use. ${ }^{191}$ In assessing transformative use under factor one, the court largely ignored Benjamin's assertion that his editing constitutes criticism, instead focusing its analysis on the video's pejorative title, the "broader context of Benjamin's YouTube channel[] where it was posted," and his choice of "excerpt[s] ... to depict the specific moments he felt exemplified Hughes's political identity and lack of awareness." 192 Although the reference to Benjamin's choice of excerpts might be an oblique reference to the video's editing, ${ }^{193}$ the court's analysis of the excerpts differs from a substantive discussion of the video's editing in several key respects. The court explains that Benjamin chose to include footage that supported his critique of "Hughes's political

183. Hughes, 437 F. Supp. 3d at 387.

184. Id. at 387-88. The court explains that the term "'SJW' or 'social justice warrior' is a term routinely used by Benjamin in a demeaning context to belittle proponents of perceived liberal social policies and stances." $I d$. at 388 .

185. Id. at 388.

186. Compare Hughes's original video, Akilah Obviously, We Thought She Would Win | Akilah Obviously, YouTUBE (Nov. 18, 2016), https://perma.cc/S77U-ZPWW, with the transcript of Benjamin's video, Declaration of Wesley Mullen in Support re: 30 Motion to Dismiss, Exhibit D - Transcript of Critical Video, Hughes v. Benjamin, 437 F. Supp. 3d 382 (S.D.N.Y. 2020) (No. 17-CV-6493 (RJS)) [hereinafter Benjamin Video Transcript].

187. Hughes, 437 F. Supp. 3d at 388 .

188. Complaint at 5, Hughes v. Benjamin, 437 F. Supp. 3d 382 (S.D.N.Y. 2020) (No. 17-CV-6493 (RJS)).

189. Memorandum of Law in Support of Sargon of Akkad's Motion to Dismiss at 5, Hughes v. Benjamin, 437 F. Supp. 3d 382 (S.D.N.Y. 2020) (No. 17-CV-6493 (RJS)) [hereinafter Benjamin Memorandum].

190. Id. at 10

191. Hughes, 437 F. Supp. 3d at 394.

192. Id. at 392.

193. The words "edit" and "editing" appear nowhere in the court's opinion. 
identity and lack of awareness ... while omitting footage that did not support his message." 194 The court concluded that Benjamin chose these excerpts "to maximize his criticism of Hughes's liberal viewpoint." 195 However, this analysis focuses solely on the content of the clips Benjamin excerpted from Hughes's video; it does not discuss the arrangement of these clips in sequence or how the juxtaposition of specific clips, once so arranged, advances Benjamin's critique. Because editing is the primary means through which Benjamin articulates his criticism-his video contains no original footage - the court's silence on the video's editing is perplexing, and its analysis of the video's transformativeness under factor one is incomplete.

Had the court undertaken a thorough analysis of the video's editing, it very likely would have concluded that Benjamin's selective editing of the Hughes video conveys his criticism to the audience. Hughes's video intercuts footage Hughes took at the Clinton election night party with her thoughts and opinions about the election night, Clinton's loss, and what it means for the country. Hughes's video contains a distinct point of view; she is unsettled and disappointed about the election of Donald Trump, and she believes Trump's election reveals that there are "plenty of people whose best interest is to keep everyone divided ... and to give them a scapegoat." 196 Hughes then implores viewers to speak up when family members espouse sexist, racist, homophobic, or xenophobic views, explaining that "we can't live in a society where there are two Americas." 197 She then talks about her concerns with healthcare access and the value of YouTube as a platform. Towards the end of the video, Hughes takes solace in the fact that she lives in New York: "I think what's helpful for me is that I live in New York. I'm surrounded by like-minded people. People here are disgusted and we're not going to take it." 198

In contrast, Benjamin's video takes selected clips from the Hughes video and presents them to the viewer in such a way that Hughes appears to contradict herself or make conflicting statements in quick succession. The Benjamin video is composed of six short clips of the Hughes video that Benjamin pulled from the larger Hughes video. ${ }^{199}$ Specifically, Benjamin's video selectively pulls the three clips quoted in the paragraph above and edits these clips so that they quickly play one after another. He pairs Hughes's statements criticizing people in society whose "best interest is to keep everyone divided" and her statement that "we can't live in a society where there are two Americas" with her statement that she is grateful she lives in New York "surrounded by like-minded people." 200

Benjamin's editing choices are the primary means through which he generates his criticism. By juxtaposing Hughes's statements rejecting societal division and two Americas with Hughes's later statement expressing gratitude that she lives in New York "surrounded by like-minded people," the critical intent of Benjamin's editing

\footnotetext{
194. Hughes, 437 F. Supp. 3d at 392.

195. Id.

196. See Akilah Obviously, supra note 186 (at $05: 15$ of the video).

197. Id. (at $06: 25$ of the video).

198. Id. (at 09:09 of the video).

199. See Benjamin Video Transcript, supra note 186, at 2-3.

200. Id.
} 
can be reasonably perceived. He believes the fact that Hughes espouses societal unity in one moment and embraces life surrounded by "like-minded people" in another moment is contradictory, and is thus a ripe target for his criticism. ${ }^{201}$ Benjamin uses quick cuts to bring together several Hughes statements - statements spoken many minutes apart in her initial video - and force the viewer to consider the veracity of the statements when played one after another in succession. Thus, although Benjamin's video adds no original spoken or textual critical elements apart from its title, it nonetheless uses the process of editing to create critical meaning through the specific ordering of its shots. Benjamin's editing is meaning-generating in itself, and it is through his editing - more than any other element - that Benjamin creates a transformative work that "adds something new, with a further purpose or different character, altering the first with new expression, meaning, or message."202

In short, had the court used film studies-specific interpretive tools to analyze Benjamin's video, it likely would have held that the video's editing-the juxtaposition of specific clips in which Hughes makes seemingly contradictory statements - evinces the work's transformative critical purpose. ${ }^{203}$ Such an analysis not only reinforces the court's finding that the Benjamin video is transformative under factor one of the fair use test, it more accurately describes the extent to which Benjamin's video conveys critical meaning to the audience.

\section{CONCLUSION}

Criticism is a creative form, and as such, critics use a variety of elements at their disposal to sharpen their critical tongue and express their commentary in novel and interesting ways. This is particularly true for creators of audiovisual criticism. The audiovisual form gives critics a new dimension in which to express their criticism; creators of audiovisual criticism are not merely limited to spoken dialogue or text to express their criticism, instead utilizing filmic, visual, and video-specific techniques in tandem with dialogue and text to craft a cohesive and fully-realized critical work. Many makers of YouTube reaction videos and video essays recognize the vast manipulability of the audiovisual form, and they deliberately manipulate these visual and filmic elements to advance their critical aims.

As the market for online audiovisual content continues to develop, courts will increasingly grapple with fair use issues involving YouTube reaction videos, video essays, and other forms of online audiovisual criticism. In turn, courts are going to more frequently encounter forms of criticism that do not clearly lend themselves to the traditional legal framework for analyzing alleged works of criticism. Rather than shoehorn a work of audiovisual criticism into the text-focused mode of analysis for

201. Id.

202. Campbell v. Acuff-Rose Music, Inc., 510 U.S. 569, 579 (1994).

203. The proposed analysis of the video's editing merely shows how a court can analyze a work's critical elements for fair use purposes. This analysis does not necessitate making normative aesthetic judgements about the criticism or weighing in on the criticism's merits, and thus it is compatible with Bleistein's principle of aesthetic nondiscrimination. See supra Part II.C. The author of this Note does not endorse Benjamin's criticism. 
written forms of criticism, courts should embrace these new forms of criticism on their own terms and develop an analytical vocabulary that allows them to both recognize and assess an audiovisual work's underlying critical content. While the film concepts introduced in this Note are merely illustrative of the analytical tools utilized in film studies contexts, they are a helpful starting point from which a court could anchor its analysis of a work of audiovisual criticism. ${ }^{204}$ Courts should also seek out additional film studies materials as necessary to guide their analysis.

Embedded in the fair use statute is a recognition that criticism is a type of work worthy of the protections of fair use. This is because criticism is transformative; it adds something new and valuable to society that Congress believes is worth protecting. When courts fail to recognize that the visual and filmic elements of an audiovisual work are capable of conveying critical meaning, courts place audiovisual criticism on unequal footing with its written counterpart, creating, in effect, a regime wherein criticism in some formats receive the protections of fair use disproportionately more than others. This stands in contrast to what the fair use doctrine has been held to protect: transformative use, regardless of format. In addition, when courts acknowledge the visual elements of an audiovisual work without explaining what role those elements played in their analysis, the makers of audiovisual criticism are unable to modulate their behavior going forward to fall within the protections of the fair use statute. By incorporating an analysis of the visual and filmic elements of audiovisual works into the legal framework for fair use criticism, courts will more accurately administer the fair use statute across creative forms, and ultimately, encourage the creation of socially-beneficial works of fair use criticism.

204. See supra Part III. 